\title{
Triassic blueschists and eclogites from northwest Turkey: vestiges of the Paleo-Tethyan subduction
}

\author{
A.I. Okay ${ }^{\mathrm{a}, *}$, O. Monod ${ }^{\mathrm{b}}$, P. Monié \\ a Avrasya Yerbilimleri Enstitüsü, Istanbul Teknik Universitesi, Ayazağa 80626, Istanbul, Turkey \\ ${ }^{\mathrm{b}}$ ISTO, UMR-CNRS 6113, Université d'Orléans, BP 6759, 45067-Orléans, France \\ ${ }^{\mathrm{c}}$ Laboratoire de Géophysique, Tectonique et Sédimentologie, UMR-CNRS 5573 UMII, Pl. E. Bataillon, 34095 Montpellier Cédex, France
}

Received 14 November 2001; accepted 10 July 2002

\begin{abstract}
Triassic eclogite and blueschist facies rocks occur as a thrust sheet, 25-km long and over 2-km thick, in an Eocene fold-andthrust belt in northwest Turkey along the İzmir-Ankara suture. The thrust sheet consists mainly of metabasites with minor marble, phyllite and metachert, and rare lenses of serpentinite. The common blueschist facies mineral assemblage in the metabasites is sodic amphibole + epidote + albite + chlorite + phengite \pm garnet. Sodic amphibole commonly shows replacement by barroisite, and there is continuous petrographic transition from blueschist-metabasites to barroisite-bearing epidoteamphibolites. Eclogite with the mineral assemblage of garnet + sodic pyroxene + sodic-calcic amphibole + epidote is found only in one locality. $P-T$ conditions of the epidote-blueschist facies metamorphism are estimated as $450 \pm 50{ }^{\circ} \mathrm{C}$ and $11 \pm 2$ kbar. The blueschist formation was followed by a decrease in pressure and increase in temperature, leading to the development of barroisite-bearing epidote-amphibolites. Phengite, sodic amphibole and barroisite $\mathrm{Ar} / \mathrm{Ar}$ ages from three metabasic rocks range between 215 and $205 \mathrm{Ma}$, and indicate Late Triassic high-pressure metamorphism. The Triassic blueschists in northwest Turkey constitute part of a much larger allochthonous tectonic unit of Triassic mafic volcanic rocks. They probably represent the upper layers of a Triassic oceanic plateau, which was accreted to the Laurasian margin during the latest Triassic. The close spatial association of the Triassic and Cretaceous blueschists along the İzmir-Ankara suture suggests that the suture represents a long-lived plate boundary of Late Palaeozoic to early Tertiary age.
\end{abstract}

(c) 2002 Elsevier Science B.V. All rights reserved.

Keywords: Blueschist; Eclogite; Triassic; Tethys; Ar/Ar data; Turkey

* Corresponding author. Tel.: +33-467-14-36-50; fax: +33-0467-54-73-62.

E-mail addresses: okay@itu.edu.tr (A.I. Okay), Olivier.Monod@univ.orleans.fr (O. Monod), monie@dstu.univ-montp2.fr (P. Monié).

\section{Introduction}

Eclogites and blueschists are among the principal markers of former convergent plate boundaries. They generally form during oceanic or continental subduction preceding the terminal continental collision. Upper Cretaceous and Tertiary blueschists and eclogites are widespread in the Alpide orogenic system 
from Spain to Turkey, and represent the period of obduction and subduction of the Mesozoic NeoTethys oceans (e.g., Okay, 1989a; Maruyama et al.,
1996). On the other hand, the existence of an older Tethyan ocean is strongly suggested by the palaeogeographic reconstructions, which all show a large

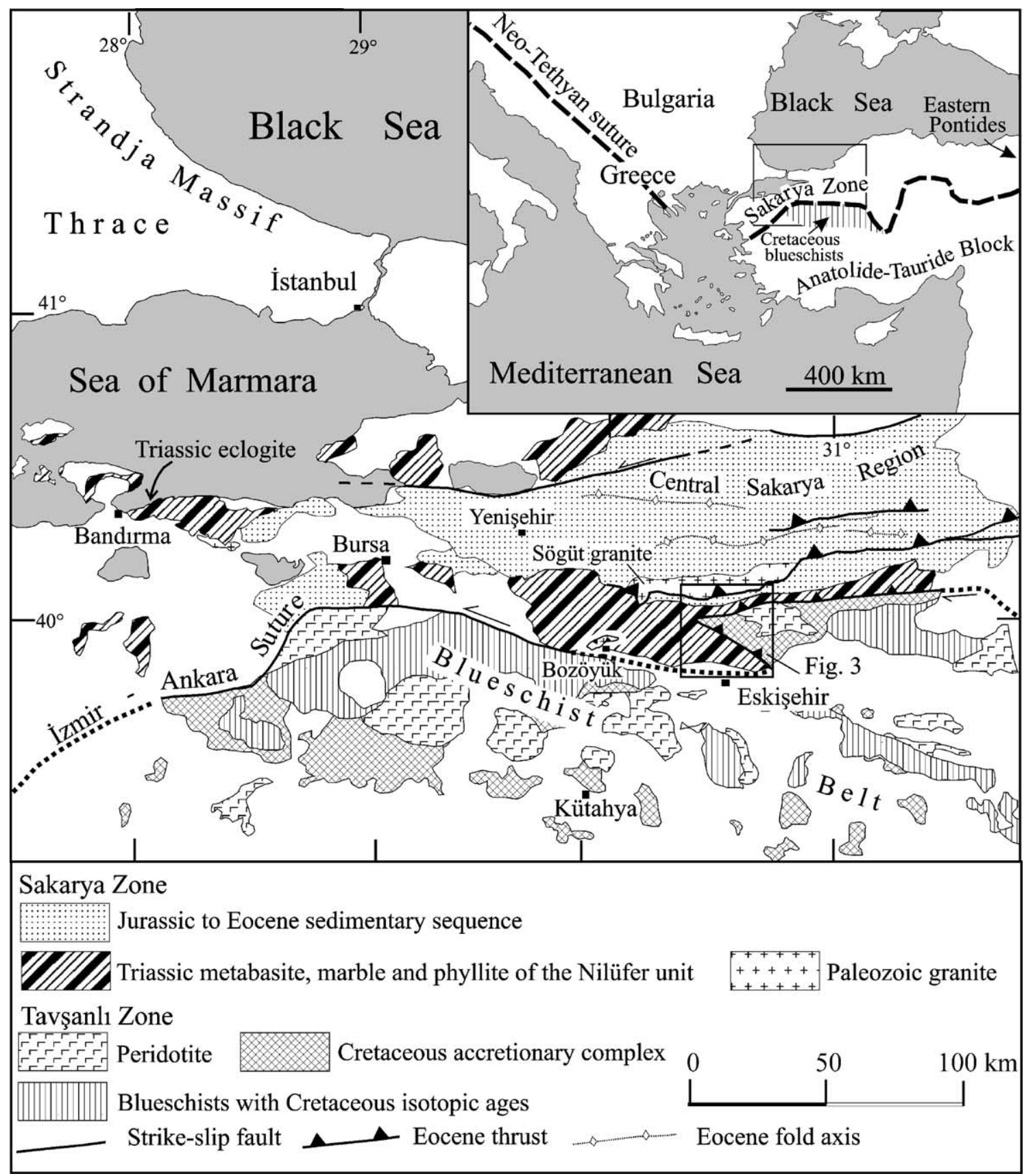

Fig. 1. Tectonic map of northwest Turkey showing the distribution of Upper Triassic and Upper Cretaceous accretionary complexes and blueschists. 
oceanic embayment between Gondwana and Laurussia during the Late Palaeozoic (e.g., Smith et al., 1981; Şengör, 1984; Jurdy et al., 1995; Stampfli and Borel, 2002). This Paleo-Tethys must have been subducted during the latest Palaeozoic and early Mesozoic, although evidence for this subduction, in terms of blueschists, accretionary complexes and magmatic arcs, has been scarce until recently. In this paper we describe a large thrust sheet of Triassic blueschists and eclogites from northwest Turkey and present data on its tectonic setting, petrology and geochronology, and discuss its significance in the Tethyan framework. Except for a single small exotic eclogite block from a different locality in northwest Turkey (Okay and Monié, 1997), these rocks constitute the only known Triassic blueschists and eclogites in the Alpide belt.

\section{Tectonic setting}

The İzmir-Ankara suture in western Anatolia forms the boundary between two former continental fragments, the Sakarya Zone in the north and the Anatolide-Tauride Block in the south (Fig. 1, Şengör and Y1lmaz, 1981; Okay and Tüysüz, 1999). The Anatolide-Tauride Block shows Gondwanian stratigraphic affinities with a Precambrian basement overlain by Palaeozoic and Mesozoic sedimentary rocks. In the Alpide orogeny it formed the footwall block, and its northern margin underwent continental subduction during the Late Cretaceous, producing a large and coherent blueschist belt, the Tavşanlı Zone (Fig. 1). Blueschists of the Tavşanlı Zone yield Late Cretaceous $\mathrm{Rb} / \mathrm{Sr}$ and $\mathrm{Ar} / \mathrm{Ar}$ ages $(\sim 80 \mathrm{Ma}$, Sherlock et al., 1999). They are tectonically overlain by an Upper Cretaceous accretionary complex and ophiolite (Okay, 1986). Unlike the Anatolide-Tauride Block, the Sakarya Zone north of the İzmir-Ankara suture shows no Alpide metamorphism. It has a basement of Upper Palaeozoic granitoids and Triassic subduction-accretion complexes, unconformably overlain by Jurassic and younger sedimentary rocks (Fig. 2; Tekeli, 1981; Okay et al., 1996).

A major component of the Triassic subductionaccretion complex of the Sakarya Zone is the Nilüfer unit, which consists of an intercalation of metabasite, marble and phyllite, over $2 \mathrm{~km}$ in thickness (Okay et

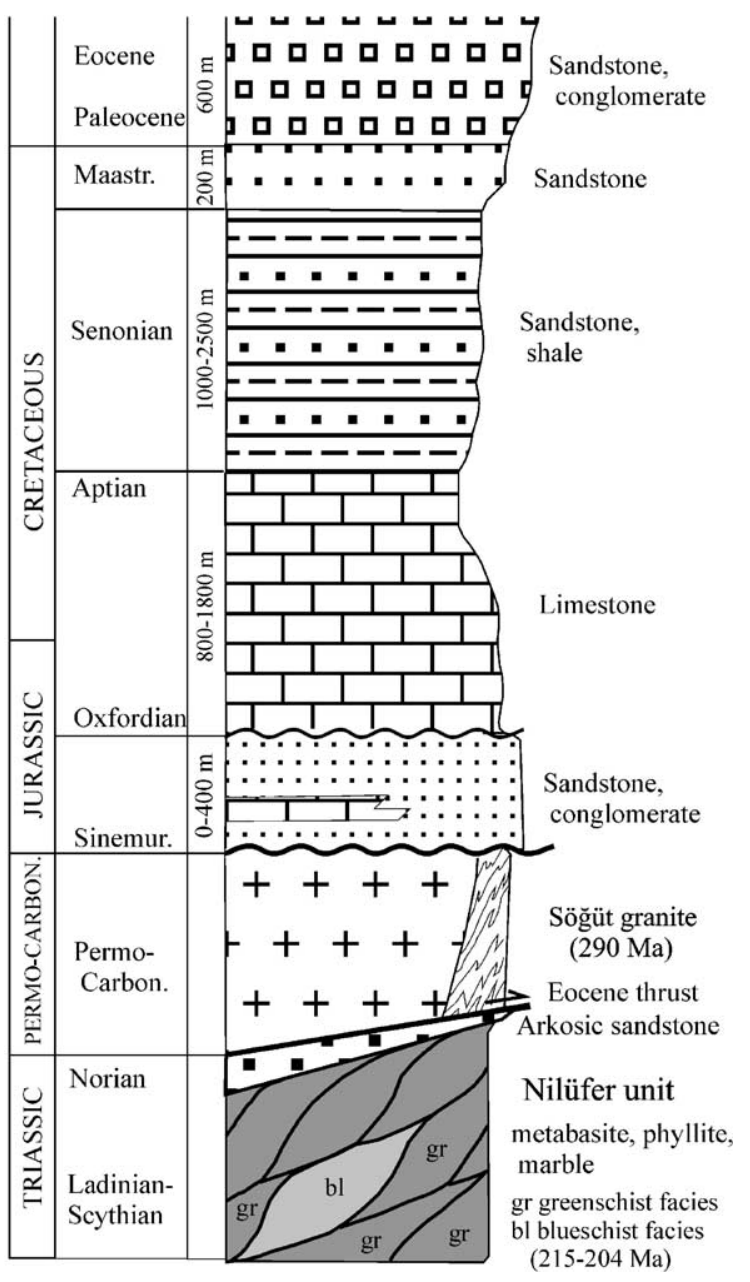

Fig. 2. Stratigraphic section of the Sakarya Zone in the central Sakarya region showing the position of the Triassic blueschists (after Altınl1, 1975; Saner, 1980; Altıner et al., 1991; Okay et al., 1996).

al., 1996). The Nilüfer unit has a very wide distribution in northern Turkey and can be traced for over $1000 \mathrm{~km}$ in the Sakarya Zone with little change in its lithological features. The metabasic rocks of the Nilüfer unit represent fine-grained mafic tuffs, pyroclastic rocks and pillow lavas. The geochemistry of the metabasic rocks and the mineral chemistry of the relict igneous pyroxenes suggest a within-plate tectonic setting (Pickett and Robertson, 1996). The marbles within the sequence have yielded Lower and Middle Triassic conodonts (Kaya and Mostler, 1992). The Nilüfer unit has been strongly deformed 
with folding, thrust imbrication and generation of foliation in the metatuffs and phyllites. Regional metamorphism in the Nilüfer unit is generally in high-pressure greenschist facies with rare and sporadic development of sodic amphibole in metabasites and metacherts (Y1lmaz, 1979; Okay, 1986; Genç and Y1lmaz, 1995; Rojay and Göncüoğlu, 1997). The Nilüfer unit shows tectonic contacts with Upper Palaeozoic granitoids and associated scarce metasedimentary host-rocks. The Sögüt granitoid, the largest of these Palaeozoic granitoids in northwest Turkey, is exposed for $75 \mathrm{~km}$ at the base of a major Eocene thrust sheet in the central Sakarya region (Fig. 1).

\section{Geology of the Triassic blueschists}

The central Sakarya region north of Eskişehir is a south-vergent fold and thrust belt formed during the Eocene continental collision between the Sakarya Zone and the Anatolide-Tauride Block (Y1lmaz, 1981; Nebert et al., 1986; Göncüoğlu et al., 2000). The folding and thrusting involved the JurassicEocene sedimentary sequence, as well as its basement of Upper Palaeozoic granitoids and the Nilüfer unit (Fig. 2). In the south along the İzmir-Ankara suture, Upper Cretaceous accretionary complex and ophiolite are also involved in the thrusting.

The Upper Palaeozoic Sögüt granitoid is exposed north of the Sakarya river at the base of a major eastwest trending thrust sheet (Fig. 1). The Sögüt granitoid is mainly a hornblende-and biotite-bearing granodiorite, which locally shows a strong gneissic layering (Y1lmaz, 1981). It is unconformably overlain by Lower Jurassic (Sinemurian) continental to shallow marine sandstones and conglomerates. The Söğüt granitoid with its Jurassic cover is thrust southward over the Palaeocene-Eocene continental clastic rocks. The thrust plane steps down westward and in the Sögüt region the granitoid lies over the Nilüfer unit (Y1lmaz, 1981). A cataclastic zone, 500-m thick, has formed at the base of the Sögüt granitoid. A klippe of the Sögüt granitoid north of Bozöyük indicates a minimum of $28 \mathrm{~km}$ southward translation along the basal thrust (Fig. 1).

Jurassic to Eocene sedimentary rocks crop out in a thrust sheet below the Sögüt granitoid along the Sakarya river (Fig. 3). These rocks are intruded by post-tectonic Miocene dacites and andesites. South of this thrust sheet runs an east-west trending tectonic belt made of imbricated slices of the Nilüfer unit, Upper Cretaceous accretionary mélange and ophiolite. Upper Cretaceous accretionary mélange wedges out westwards, so that west of Behç etiye (Fig. 3), the Nilüfer unit extends continuously for $70 \mathrm{~km}$ to the $\mathrm{Yeni}^{\circ}$ ehir region (Fig. 1). In this large area the Nilüfer unit exhibits a greenschist facies metamorphism with rare and sporadic occurrence of sodic amphibole in iron-rich metacherts (Yılmaz, 1979; Genç and Yılmaz, 1995). However, north of Eskişehir, a large thrust sheet within the Nilüfer unit is made of blueschist, eclogite and barroisite-bearing epidote-amphibolite, which are described below.

\subsection{The Muttalip thrust sheet: Nilüfer unit with eclogite and blueschist facies metamorphism}

The Muttalip thrust sheet is $25-\mathrm{km}$ long, 7-km wide and over 2-km thick (Fig. 3). In the south it is in contact with the alluvial Eskişehir plain along recent to active normal faults delineating the Eskiş ehir graben. The Muttalip thrust sheet is made predominantly of metabasic rocks, constituting $\sim 80 \%$ of the outcrops. The metabasic rocks range from epidote-blueschists to barroisite-bearing epidote-amphibolites. They are intercalated with discontinuous marble, phyllite and metachert layers, and include rare lenses of antigoriteserpentinite. Eclogite is found in only one locality. In the field, blueschists are readily identifiable on account of the common idioblastic blue sodic amphiboles, up to several millimetres across. Barroisite-bearing epidoteamphibolites frequently show the development of mesoscopic albite porphyroblasts, several millimetres large.

Rocks in the Muttalip thrust sheet show a penetrative foliation and commonly a mineralogical banding. The foliation planes form a broad and diffuse girdle around an east-west trending subhorizontal fold axis (Fig. 3, inset). In most of the outcrops, sodic amphiboles are randomly distributed in the foliation plane. However, locally a mineral lineation is noticeable in the Muttalip thrust sheet defined by large sodic amphibole crystals. The lineation trends generally north-south with a weak northward plunge (Fig. 3, inset). Tight to isoclinal folds are common, especially 


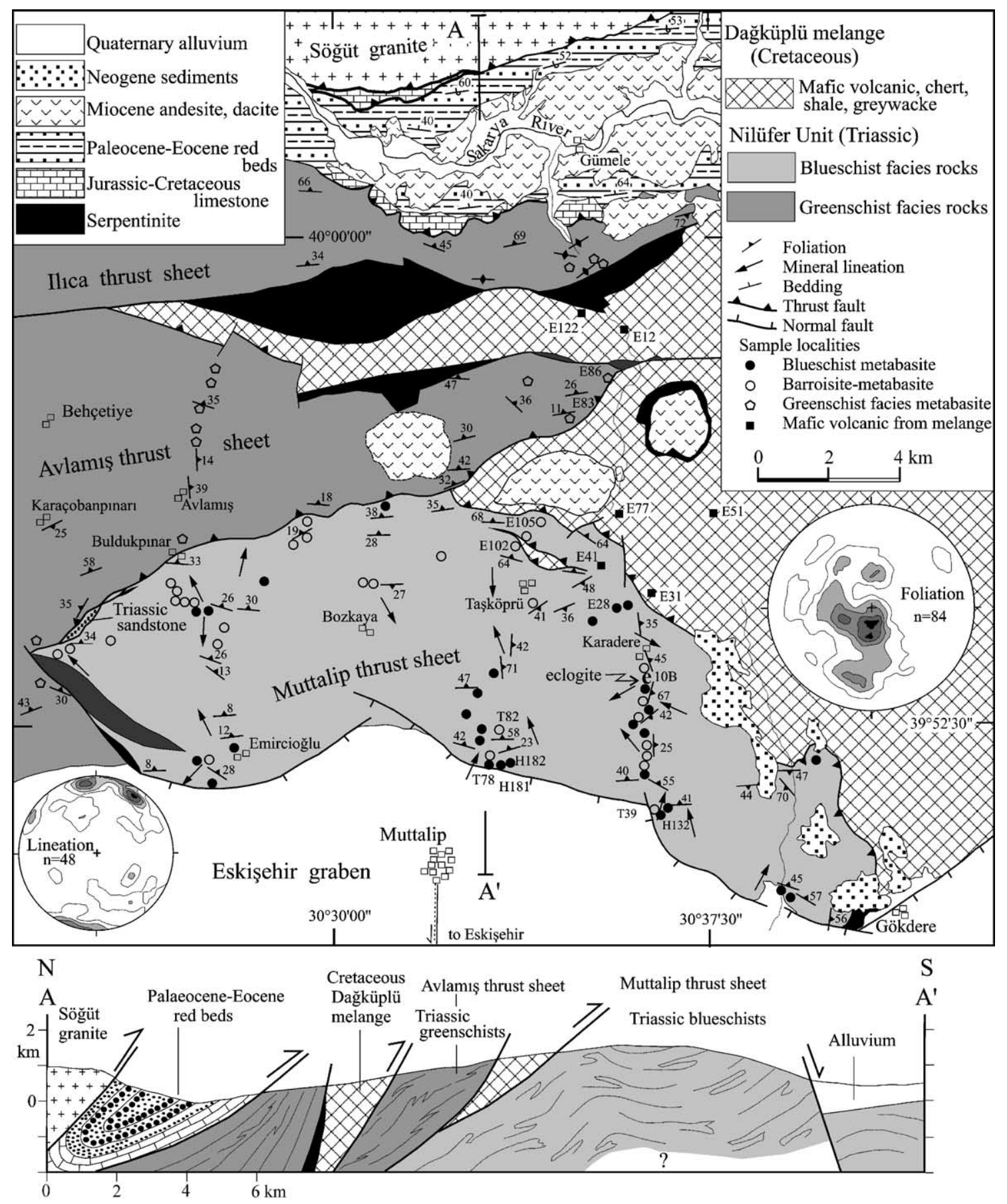

Fig. 3. Geological map and cross section of the region north of Eskişehir. For location see Fig. 1. The geology north of the Sakarya River is from Nebert et al. (1986). In the cross section post-tectonic Miocene volcanic rocks are omitted for clarity. The two insets show lower hemisphere equal-area projections of foliation and lineation, respectively, in the Muttalip thrust sheet. Contours are at 1\%, 3\%, 5\%, 7\% and 9\% per $1 \%$ area. 
in the southern part of the Muttalip thrust sheet. Fold axial planes are parallel to the foliation and the fold axes lie close to the lineation, suggesting curvilinear folds. Kinematic criteria associated with the ductile deformation include $\mathrm{C} / \mathrm{S}$ structures, pressure shadows and rotated garnets. In the field, sigmoidal structures and $\mathrm{C} / \mathrm{S}$ relationships generally indicate a top-to-thenorth sense of shear. On the other hand, in thin section, the shear sense is often ambiguous and, when determinable, shows both top-to-the-north and top-tothe-south sense of shear directions from the same area. This may suggest prevalence of pure shear conditions, at least during the later stages of the HP/LT metamorphism.

\subsection{Thrust sheets of Nilüfer unit with greenschist facies metamorphism}

Two thrust sheets of the Nilüfer unit, separated by a sliver of Upper Cretaceous accretionary mélange, occur north of the Muttalip thrust sheet (Fig. 3). The Avlamış thrust sheet lies over the Muttalip thrust sheet along a fault plane dipping north at $30-40^{\circ}$. The tectonic contact is marked by lenticular slivers of basalt, serpentinite and by arkosic sandstone of probable Late Triassic age. The Avlamış thrust sheet consists predominantly of metabasic rocks, mainly fine-grained metatuffs with rare metadiabase and metagabbro. They are intercalated with marble, phyllite and metachert. Although lithologically similar to the Muttalip thrust sheet, rocks in the Avlamıs thrust sheet have undergone only a low-grade greenschist facies metamorphism, and the igneous textures and in some cases igneous minerals are still preserved in the metabasites. Fine-grained metabasites and phyllites in the Avlamıs thrust sheet show a well-developed foliation, which dips north to northwest. No mineral lineation was observed in the Avlamıs thrust sheet. The Avlamış thrust sheet is in tectonic contact along a steeply north-dipping fault with the Ilica thrust sheet. This subvertical fault shows a linear trend for a distance of over $70 \mathrm{~km}$ (cf. Fig. 1), suggesting a major component of strike-slip motion. The Ilica thrust sheet also consists mainly of metabasic rocks with greenschist facies mineral assemblages. In the north the Ilica thrust sheet is overthrust by the Jurassic and Cretaceous limestones and Palaeocene-Eocene red beds of the Sakarya valley (Fig. 3).

\subsection{Upper Cretaceous accretionary mélange-the Dağküplü mélange}

The Dağküplü mélange consists of mafic pillow lava, agglomerate, tuff, radiolarian chert, serpentinite, pelagic limestone, pelagic shale and greywacke (Şentürk and Karaköse, 1981; Nebert et al., 1986; Göncüoğlu et al., 2000). Individual lithologies cannot be traced laterally more than a few hundred meters before they are sheared off. Penetrative foliation has only developed in the shear zones in the Dağküplü mélange. Mafic volcanic rocks in the Dağküplü mélange show an incipient blueschist metamorphism, characterized by the local development of lawsonite, sodic pyroxene and aragonite. Late Triassic (Carnian), Late Jurassic (Bathonian-Tithonian) and Early Cretaceous (Hauterivian-Aptian) ages are reported from the radiolarian cherts in the Dağküplü mélange (Göncüoğlu et al., 2000, 2001). The Dağküplü mélange represents an accretionary complex, formed during the Late Cretaceous subduction of the Neo-Tethys ocean. Such accretionary complexes are widespread along the İzmir-Ankara suture in northwest Turkey (Okay and Tüysüz, 1999). Their complex deformation is related to the Late Cretaceous accretion and obduction, and early Tertiary continental collision.

The Dağküplü mélange lies tectonically over the Muttalip thrust sheet north of Taş köprü (Fig. 3). However, this fault plane, when traced eastward, becomes overturned and north of Gökdere the Dağküplü mélange lies under the Muttalip thrust sheet along a steeply dipping $\left(\sim 60^{\circ}\right)$ fault plane. Tectonic slivers of the Dağküplü mélange occur between the thrust sheets of the Nilüfer unit (Fig. 3). In the east, the Dağküplü mélange is tectonically overlain by large bodies of gabbro and peridotite (Asutay et al., 1989).

\section{Petrology}

\subsection{Eclogite, blueschist and epidote-amphibolite of the Muttalip thrust sheet}

The metabasic rocks in the Muttalip thrust sheet comprise eclogite, epidote-blueschist and barroisitebearing epidote-amphibolite. Epidote-blueschists are better preserved in the eastern part of the Muttalip 
thrust sheet, although meter-scale intercalations of epidote-amphibolite and epidote-blueschist are present even in regions with best-preserved blueschists. Eclogite is found in only one locality south of the village of Karadere (Fig. 3). It forms a 3-m-thick elongate lens dipping southeast and surrounded on both sides by garnet-amphibolite, 3-m thick. The garnet-amphibolite envelope around the eclogite lacks high-pressure minerals and consists of garnet, sodic-calcic amphibole, epidote, phengite and sphene. The garnet-amphibolite is underlain through a 1-mthick phyllite horizon by blueschist metacherts with crossite, garnet, quartz and phengite.

The main minerals in the eclogite are garnet, sodic pyroxene, amphibole, albite and phengite (Fig. 4a, Table 1). Sodic pyroxene forms prismatic crystals, up
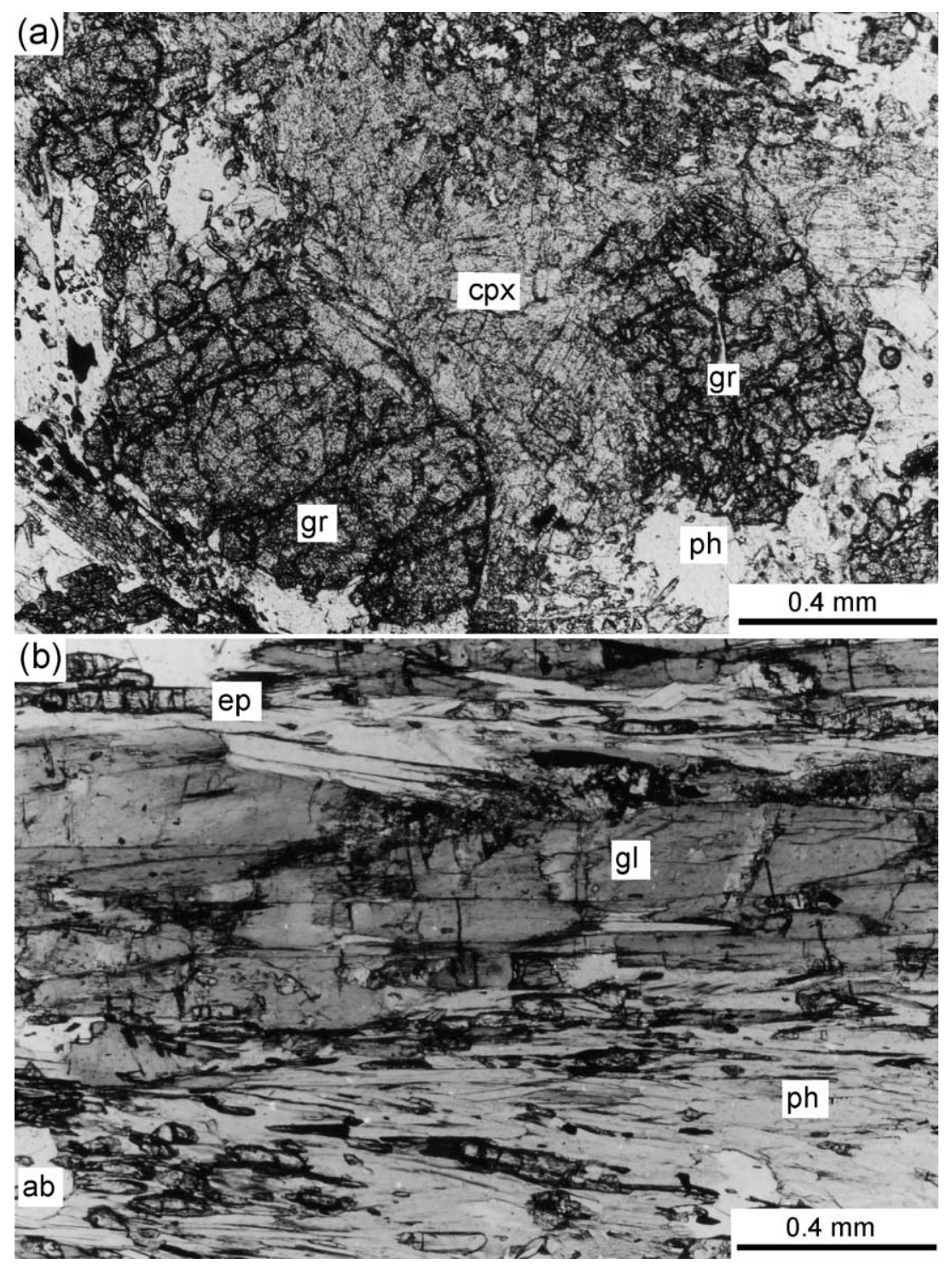

Fig. 4. Photomicrographs from the Muttalip thrust sheet. (a) Eclogite with garnet (gr), sodic pyroxene (cpx) and phengite (ph). Sample 10B, plane polarised light. (b) Blueschist-metabasite with glaucophane (gl), phengite (ph), epidote (ep) and albite (ab). Phengite and glaucophane from this sample were used for Ar-Ar dating. Sample T78, plane polarised light. 
Table 1

Estimated mineral modes of the analysed rocks in the Nilüfer unit

\begin{tabular}{|c|c|c|c|c|c|c|c|c|c|c|c|c|}
\hline & \multicolumn{10}{|c|}{ Muttalip thrust sheet } & \multirow{2}{*}{\multicolumn{2}{|c|}{$\frac{\text { Avlamış thrust sheet }}{\text { metabasite }}$}} \\
\hline & \multirow{2}{*}{$\frac{\text { Eclogite }}{10 \mathrm{~B}}$} & \multicolumn{4}{|c|}{ Blueschist-metabasite } & \multirow{2}{*}{$\frac{\text { Metachert }}{\text { H181 }}$} & \multicolumn{4}{|c|}{ Epidote-amphibolite } & & \\
\hline & & H132 & $\mathrm{H} 182$ & E28 & $\mathrm{T} 78$ & & E102 & E105 & T39 & $\mathrm{T} 82$ & E83 & E86 \\
\hline Sodic pyroxene & 27 & - & - & - & - & - & - & - & - & - & - & - \\
\hline Garnet & 21 & - & - & - & & 1 & - & 5 & - & - & - & - \\
\hline Sodic amphibole & - & 33 & 43 & 18 & 38 & 19 & - & - & - & - & - & - \\
\hline $\mathrm{Na}-\mathrm{Ca}$ amphibole & 13 & - & - & - & 2 & - & 31 & 19 & 41 & 6 & - & - \\
\hline Ca-amphibole & - & - & - & - & - & - & - & - & - & - & 25 & 38 \\
\hline Epidote & 3 & 31 & 36 & 12 & 19 & - & 13 & 10 & 38 & 19 & 16 & 8 \\
\hline Albite & 12 & 5 & 2 & - & 11 & 3 & 28 & 20 & 1 & 34 & 20 & 35 \\
\hline Chlorite & - & 8 & 2 & 4 & 4 & - & 17 & 22 & 1 & 32 & 23 & 12 \\
\hline Phengite & 15 & 17 & 9 & 18 & 18 & 21 & 1 & 16 & 2 & 7 & 1 & - \\
\hline Calcite & - & 3 & 4 & 10 & 6 & - & - & - & 12 & 1 & 4 & - \\
\hline Quartz & 1 & 2 & 1 & 34 & & 51 & 2 & 1 & - & - & 2 & - \\
\hline Leucoxene & 4 & - & - & tr. & - & - & 7 & 7 & 4 & 1 & 6 & 5 \\
\hline Rutile & 2 & - & 1 & - & 1 & - & 1 & - & - & - & - & - \\
\hline Opaque & 2 pyr & 1 & $2 \mathrm{he}$ & 4 & 1 & 5he & - & - & 1 & - & 3 & 2 \\
\hline Other & ap & & & & & tour & & & & & & \\
\hline
\end{tabular}

tr., $<0.5$; pyr, pyrite; he, hematite; ap, apatite; tour, tourmaline.

to 5-mm long, partially replaced by albite and sodiccalcic amphibole of katophorite composition. Sodic pyroxene is associated with smaller poikilitic garnet grains, which have inclusions of epidote, phengite and glaucophane. Amphibole in the matrix of the eclogite is a dark greenish blue katophorite after the amphibole nomenclature scheme of Leake et al. (1997). Glaucophane with rims of katophorite is only found as inclusions in garnet grains. Garnets from the eclogite are almandine-grossular solid solutions with minor pyrope $(<9 \mathrm{~mol} \%)$ and spessartine $(<8 \mathrm{~mol} \%)$ components (Table 2). They show a distinct growth zoning involving an increase in almandine and pyrope, and a decrease of grossular and spessartine components and $\mathrm{Fe} / \mathrm{Mg}$ ratio towards the rim (Fig. 5). The sodic pyroxene compositions concentrate on two main compositional groups: an omphacitic pyroxene (jadeite contents $\sim 50 \mathrm{~mol} \%$ ) and a jadeitic (jadeite contents $\sim 70$ mol\%) pyroxene (Fig. 6). Petrographically there is no clear zoning pattern, and these two sodic pyroxene compositions form irregular patches even within a single grain (Fig. 5).

Epidote-blueschist metabasites in the Muttalip thrust sheet form medium-grained, strongly foliated, commonly banded and lineated rocks. The typical mineral assemblage in the pristine blueschists is sodic amphibole + epidote + albite + chlorite + phengite + ru- tile/sphene \pm garnet \pm calcite \pm quartz (Table 1$)$. The foliation is defined by the alignment of sodic amphibole, chlorite, phengite and epidote grains, and the mineralogical banding generally involves modal variation of epidote (Fig. 4b). Garnet is present in less than a quarter of samples, where it occurs as rotated porphyroblasts with inclusions of sodic amphibole, epidote and quartz. Sodic amphibole generally forms idioblastic grains, commonly with a distinct rim of optically continuous bluish-green barroisite. Four blueschist metabasites were analysed with an SX-50 Cameca electron microprobe in the Bureau de Recherches Géologiques et Miniéres in Orléans, France. Operating conditions were $15-\mathrm{kV}$ accelerating voltage, 12 -nA beam current and $1-\mu \mathrm{m}$ beam size. The estimated modes of the analysed specimens are given in Table 1, and representative mineral compositions in Table 2. The ferric iron was estimated in sodic pyroxene on the basis of $\mathrm{Fe}^{3+}=\mathrm{Na}-\mathrm{Al}^{\mathrm{vi}}$ in a four-cation structural formula, in sodic amphibole on the basis of 23 oxygens and 15 cations, and in sodic-calcic and calcic amphiboles on the basis of 23 oxygens and $\mathrm{Si}+\mathrm{Ti}+\mathrm{Cr}+\mathrm{Al}+\mathrm{Fe}^{3+}+\mathrm{Fe}^{2+}+\mathrm{Mg}+\mathrm{Mn}=13$.

In the epidote-blueschists, sodic amphibole is glaucophane to crossite in composition with a low $X_{\mathrm{Ca}}$ value $(\mathrm{Ca} /(\mathrm{Ca}+\mathrm{Na})<0.06)$ (Fig. 6). The pistacite component of the epidote ranges from 26 to $33 \mathrm{~mol} \%$. 
Table 2

Representative mineral compositions from the Triassic eclogite, blueschist and barroisite-amphibolite from the Nilüfer unit, northwest Turkey

\begin{tabular}{|c|c|c|c|c|c|c|c|c|c|c|c|c|c|c|c|c|c|c|c|}
\hline & \multicolumn{6}{|c|}{ Eclogite 10B } & \multicolumn{4}{|c|}{ Blueschist T78 } & \multicolumn{4}{|c|}{ Blueschist H132 } & \multicolumn{5}{|c|}{ Barroisite-amphibolite E105 } \\
\hline & \multicolumn{2}{|l|}{ Garnet } & \multirow[t]{2}{*}{ Amph. } & \multicolumn{2}{|c|}{ Sodic pyroxene } & \multirow[t]{2}{*}{ Pheng. } & \multirow[t]{2}{*}{ Amph. } & \multirow[t]{2}{*}{ Chlorite } & \multirow[t]{2}{*}{ Epidote } & \multirow[t]{2}{*}{ Pheng. } & \multirow[t]{2}{*}{ Amph. } & \multirow[t]{2}{*}{ Chlorite } & \multirow[t]{2}{*}{ Epidote } & \multirow[t]{2}{*}{ Pheng. } & \multirow[t]{2}{*}{ Garnet } & \multirow[t]{2}{*}{ Amph. } & \multirow[t]{2}{*}{ Chlorite } & \multirow[t]{2}{*}{ Epidote } & \multirow[t]{2}{*}{ Pheng. } \\
\hline & core & rim & & & & & & & & & & & & & & & & & \\
\hline $\mathrm{SiO}_{2}$ & 38.79 & 39.18 & 47.06 & 59.5 & 57.19 & 49.26 & 56.18 & 26.28 & 37.82 & 49.20 & 57.49 & 26.74 & 38.41 & 50.03 & 37.99 & 49.65 & 26.73 & 38.34 & 49.10 \\
\hline $\mathrm{TiO}_{2}$ & 0.00 & 0.07 & 0.18 & 0.06 & 0.04 & 0.19 & 0.00 & 0.01 & 0.01 & 0.16 & 0.01 & 0.00 & 0.16 & 0.26 & 0.00 & 0.21 & 0.00 & 0.00 & 0.32 \\
\hline $\mathrm{Al}_{2} \mathrm{O}_{3}$ & 21.41 & 21.77 & 12.42 & 19.47 & 12.28 & 27.41 & 8.64 & 19.96 & 23.52 & 26.67 & 9.70 & 19.80 & 22.12 & 27.50 & 21.33 & 11.21 & 20.93 & 27.40 & 27.15 \\
\hline $\mathrm{Cr}_{2} \mathrm{O}_{3}$ & 0.05 & 0.06 & 0.12 & 0.00 & 0.00 & 0.00 & 0.05 & 0.00 & 0.00 & 0.00 & 0.00 & 0.00 & 0.00 & 0.09 & 0.00 & 0.11 & 0.00 & 0.00 & 0.00 \\
\hline $\mathrm{FeO}$ & 24.50 & 26.37 & 17.76 & 5.40 & 6.54 & 3.61 & 13.86 & 21.30 & 12.31 & 4.39 & 14.38 & 21.87 & 14.48 & 4.28 & 26.15 & 13.39 & 23.13 & 7.47 & 2.47 \\
\hline $\mathrm{MgO}$ & 0.58 & 2.03 & 7.47 & 1.34 & 5.27 & 2.56 & 9.24 & 17.64 & 0.03 & 2.87 & 8.42 & 17.37 & 0.01 & 2.65 & 1.18 & 10.99 & 17.26 & 0.00 & 2.70 \\
\hline $\mathrm{MnO}$ & 1.71 & 0.28 & 0.15 & 0.01 & 0.02 & 0.00 & 0.00 & 0.10 & 0.14 & 0.05 & 0.00 & 0.17 & 0.32 & 0.01 & 1.57 & 0.00 & 0.11 & 0.00 & 0.00 \\
\hline $\mathrm{CaO}$ & 13.96 & 11.08 & 4.98 & 2.69 & 9.36 & 0.00 & 0.74 & 0.04 & 22.99 & 0.03 & 0.69 & 0.04 & 21.75 & 0.00 & 11.66 & 7.61 & 0.10 & 22.59 & 0.00 \\
\hline $\mathrm{Na}_{2} \mathrm{O}$ & 0.04 & 0.06 & 6.79 & 13.34 & 9.31 & 0.60 & 6.72 & 0.00 & 0.00 & 0.56 & 7.14 & 0.04 & 0.05 & 0.47 & 0.00 & 3.72 & 0.00 & 0.00 & 0.35 \\
\hline $\mathrm{K}_{2} \mathrm{O}$ & 0.01 & 0.02 & 0.50 & 0.01 & 0.00 & 9.89 & 0.03 & 0.00 & 0.03 & 10.27 & 0.04 & 0.05 & 0.03 & 10.36 & 0.00 & 0.20 & 0.00 & 0.00 & 10.51 \\
\hline Total & 100.60 & 100.92 & 97.43 & 101.82 & 100.01 & 93.52 & 95.46 & 85.33 & 96.85 & 94.20 & 97.87 & 86.08 & 97.33 & 96.65 & 99.88 & 97.09 & 88.26 & 95.80 & 92.60 \\
\hline \multicolumn{20}{|c|}{ Mineral formula on the basis of } \\
\hline & 12 oxy. & & 23 oxy. & 4 cat. & & 11 oxy. & 23 oxy. & 28 oxy. & 8 cat. & 11 oxy. & 23 oxy. & 28 oxy. & 8 cat. & 11 oxy. & 12 oxy. & 23 oxy. & 28 oxy. & 8 cat. & 11 oxy. \\
\hline $\mathrm{Si}$ & 3.044 & 3.047 & 6.948 & 2.021 & 2.023 & 3.366 & 7.978 & 5.570 & 3.005 & 3.364 & 7.974 & 5.633 & 3.059 & 3.360 & 3.013 & 7.118 & 5.514 & 3.034 & 3.380 \\
\hline $\mathrm{Al}^{\mathrm{IV}}$ & & & 1.052 & & & 0.634 & 0.022 & 2.430 & & 0.636 & 0.026 & 2.367 & & 0.640 & & 0.882 & 2.486 & & 0.620 \\
\hline $\mathrm{Al}^{\mathrm{VI}}$ & 1.980 & 1.995 & 1.109 & 0.780 & 0.512 & 1.573 & 1.424 & 2.556 & 2.203 & 1.513 & 1.560 & 2.547 & 2.077 & 1.537 & 1.995 & 1.013 & 2.604 & 2.556 & 1.583 \\
\hline $\mathrm{Ti}$ & 0.000 & 0.004 & 0.020 & 0.001 & 0.001 & 0.100 & 0.000 & 0.001 & 0.000 & 0.008 & 0.001 & 0.000 & 0.010 & 0.013 & 0.000 & 0.023 & 0.000 & 0.000 & 0.017 \\
\hline $\mathrm{Cr}$ & 0.003 & 0.004 & 0.014 & 0.000 & 0.000 & 0.000 & 0.005 & 0.000 & 0.000 & 0.000 & 0.000 & 0.000 & 0.000 & 0.005 & 0.000 & 0.013 & 0.000 & 0.000 & 0.000 \\
\hline $\mathrm{Fe}^{3+}$ & 0.013 & & 0.251 & 0.098 & 0.126 & & 0.450 & & 0.818 & & 0.389 & & 0.964 & & 0.005 & 0.338 & & 0.494 & \\
\hline $\mathrm{Fe}^{2+}$ & 1.565 & 1.715 & 1.942 & 0.056 & 0.067 & 0.206 & 1.196 & 3.777 & & 0.251 & 1.279 & 3.852 & & 0.241 & 1.730 & 1.268 & 3.989 & & 0.142 \\
\hline $\mathrm{Mg}$ & 0.068 & 0.236 & 1.644 & 0.068 & 0.278 & 0.261 & 1.955 & 5.573 & 0.004 & 0.292 & 1.740 & 5.454 & 0.002 & 0.265 & 0.139 & 2.347 & 5.307 & 0.000 & 0.278 \\
\hline $\mathrm{Mn}$ & 0.113 & 0.019 & 0.019 & 0.000 & 0.001 & 0.000 & 0.000 & 0.019 & 0.010 & 0.003 & 0.000 & 0.031 & 0.022 & 0.001 & 0.105 & 0.000 & 0.020 & 0.000 & 0.000 \\
\hline $\mathrm{Ca}$ & 1.173 & 0.924 & 0.793 & 0.098 & 0.354 & 0.000 & 0.113 & 0.009 & 1.958 & 0.002 & 0.103 & 0.009 & 1.856 & 0.000 & 0.991 & 1.178 & 0.021 & 1.916 & 0.000 \\
\hline $\mathrm{Na}$ & 0.006 & 0.009 & 1.957 & 0.878 & 0.638 & 0.080 & 1.851 & 0.000 & 0.000 & 0.075 & 1.921 & 0.015 & 0.007 & 0.062 & 0.000 & 1.043 & 0.000 & 0.000 & 0.047 \\
\hline K & 0.001 & 0.002 & 0.094 & 0.000 & 0.000 & 0.862 & 0.006 & 0.000 & 0.002 & 0.896 & 0.008 & 0.012 & 0.003 & 0.888 & 0.000 & 0.037 & 0.000 & 0.000 & 0.923 \\
\hline Total & 7.966 & 7.955 & 15.843 & 4.000 & 4.000 & 7.082 & 15.000 & 19.935 & 8.000 & 7.040 & 15.001 & 19.920 & 8.000 & 7.012 & 7.978 & 14.260 & 19.941 & 8.000 & 6.990 \\
\hline alm & 53.6 & 59.3 & $\mathrm{jd}$ & 78 & 51 & & & & & & & & & alm & 58.4 & & & & \\
\hline pyr & 2.3 & 8.2 & aeg & 10 & 13 & & & & & & & & & pyr & 4.7 & & & & \\
\hline spess & 3.9 & 0.7 & aug & 12 & 36 & & & & & & & & & spess & 3.5 & & & & \\
\hline gros & 40.2 & 31.9 & & & & & & & & & & & & gros & 33.4 & & & & \\
\hline
\end{tabular}

oxy., oxygens; cat., cations. 


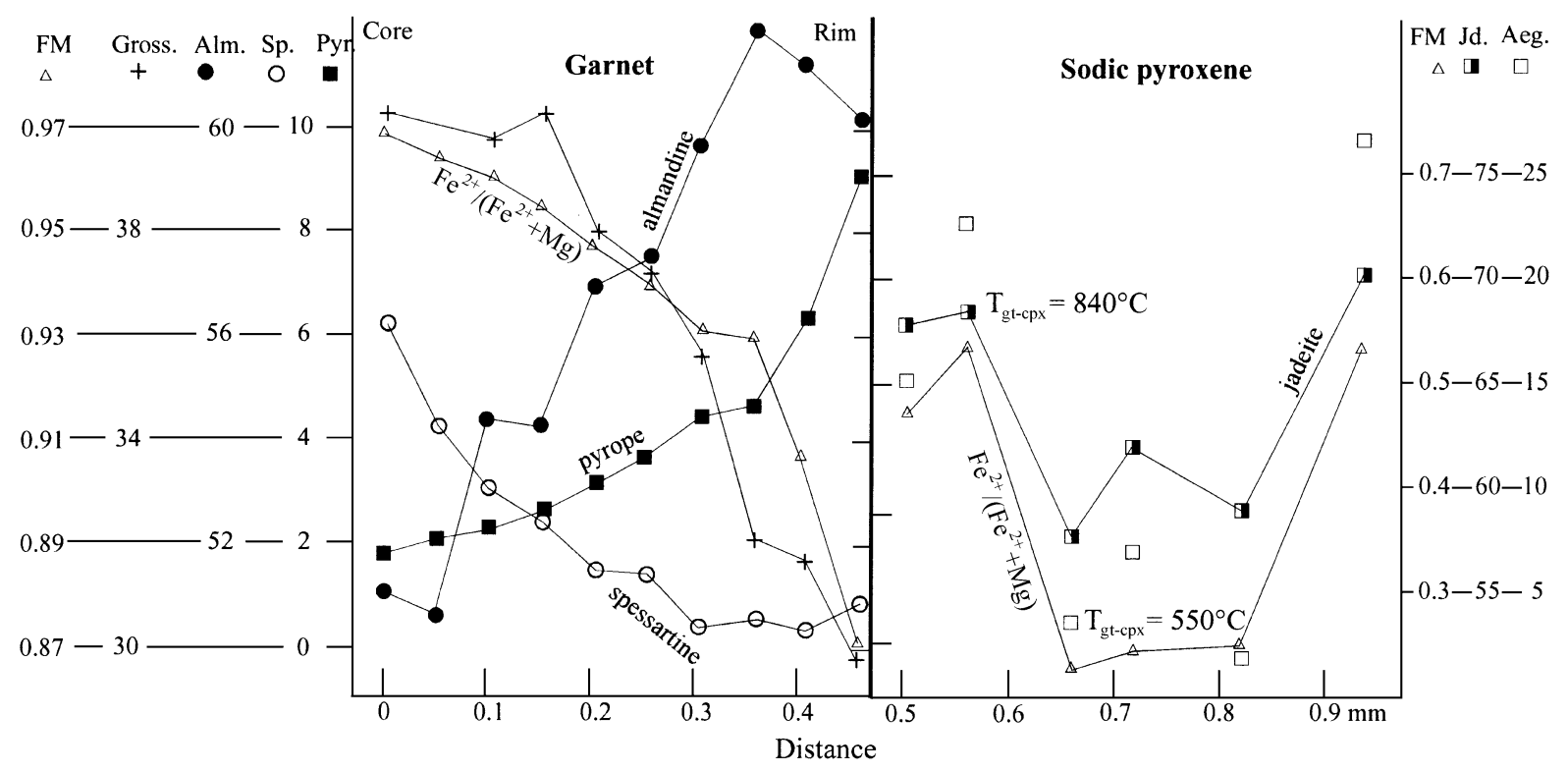

Fig. 5. Garnet to sodic pyroxene zoning profile from the eclogite 10B. Note the regular zoning in garnet, and the domainal composition in sodic pyroxene. The metamorphic temperatures shown are calculated for a pressure of $12 \mathrm{kbar}$ using the Ellis and Green (1979) garnet-clinopyroxene geothermometer. Abbreviations: $\mathrm{FM}, \mathrm{Fe}^{2+} /\left(\mathrm{Fe}^{2+}+\mathrm{Mg}\right)$.

Albite is nearly pure with very minor anorthite and $\mathrm{K}$-feldspar components (less than $1 \mathrm{~mol} \%$ each). The Si content of phengite ranges from 3.33 to 3.43 per formula unit based on 11 oxygens (Fig. 7).

Metacherts in the Muttalip thrust sheet are characterized by banding that is typically on a millimetre scale and involves rhythmic alternation of quartz-rich and ferromagnesian-mineral-rich layers. Typical mineral assemblage in the blueschist metacherts is sodic amphibole + phengite + garnet + albite + quartz + hematite. Sodic amphibole is crossite to glaucophane in composition; garnet is rich in spessartine component typical for the metacherts. Phengite and albite compositions are similar to those from the metabasites.

In the epidote-amphibolites, barroisite takes the place of sodic amphibole; otherwise, the mineral assemblage is the same as in the blueschists. In most metabasite samples, barroisite was observed as rims around blue sodic amphibole, indicating that barroisite was formed later than and at the expense of sodic amphibole. There is a continuous petrographic transition from pristine blueschist-metabasites to epidote-amphibolites free of sodic amphibole. The transition is generally marked by an increase in the modal amounts of chlorite and albite at the expense of sodic amphibole. In epidote-amphibolites, albite commonly forms poikilitic porphyroblasts, up to several millimetres across, with inclusions of epidote, chlorite and phengite, giving a spotted appearance to the rock. Four samples of amphibolites were analysed by the electron microprobe (Table 1). In three samples the amphibole is barroisite, in one coarse-grained metabasite it is katophorite (Tables 2 and 3, Fig. 6). Chlorite and, interestingly, potassic white mica compositions from the epidote-amphibolites are similar to those from the blueschist-metabasites (Figs. 7 and 8). Epidote from the epidote-amphibolites shows a wide range in composition with pistacite component ranging from 16 to $33 \mathrm{~mol} \%$.

\subsection{P-T evolution of the eclogite, blueschist and epidote-amphibolite}

The inferred peak mineral assemblage in the eclogite is garnet + sodic pyroxene + glaucophane + epidote + phengite + quartz + rutile. The jadeite content of sodic pyroxene in the eclogite indicates a minimum 


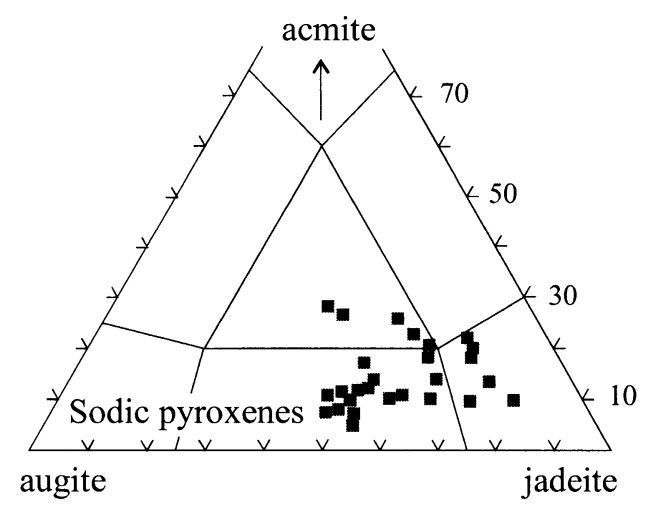

\section{Eclogite: - 10B}

Blueschist metabasite and metachert:

$\square \mathrm{H} 132 \square \mathrm{H} 182 \square \mathrm{E} 28 \bullet \mathrm{T} 78$

$\triangle \mathrm{H} 181$

Barroisite-metabasite:

$\nabla$ E102 $\triangle$ E105 $\Delta$ T39 O T82

Greenschist metabasite:

$\triangle \mathrm{E} 83 \backsim \mathrm{E} 86$
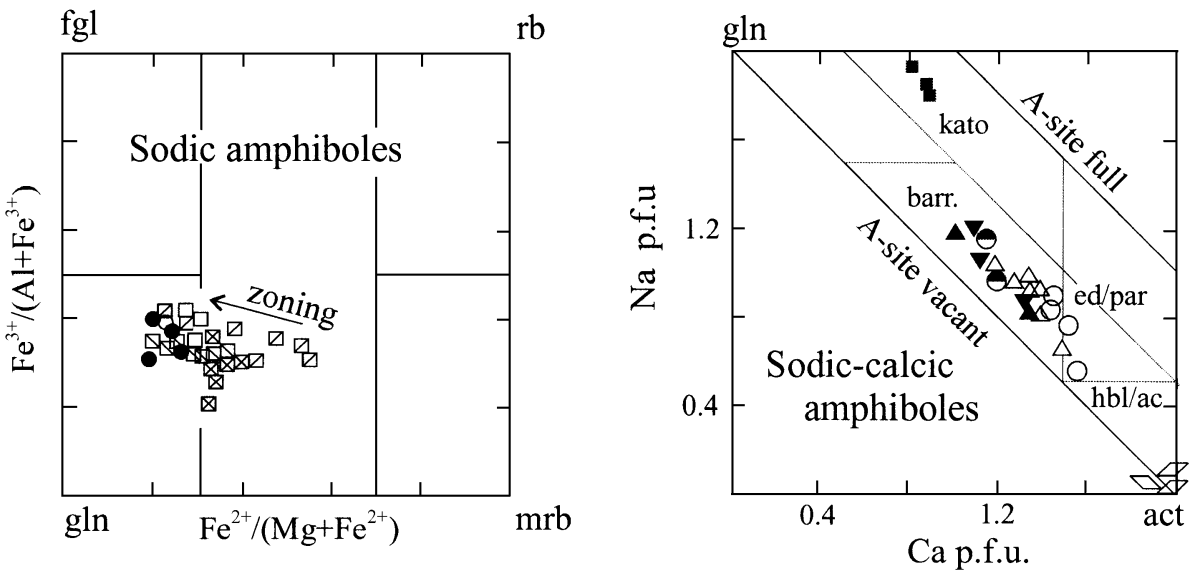

Fig. 6. Sodic pyroxene and sodic amphibole compositions from the blueschist facies and greenschist facies Nilüfer unit. Abbreviations: barr, barroisite; kato, katophorite; ed/par, edenite/pargasite; hbl/ac, hornblende/actinolite; gln, glaucophane; fgl, ferroglaucophane; rb, riebeckite; mrb, magnesioriebeckite.

pressure of $13 \mathrm{kbar}$ at $500{ }^{\circ} \mathrm{C}$ on the basis of the reaction:

$$
\text { Albite }=\text { jadeite }+ \text { quartz }
$$

Garnet-clinopyroxene geothermometer is commonly used to estimate the metamorphic temperatures in the eclogites. Traverses were made across six different garnet-clinopyroxene contacts in the eclogite sample $10 \mathrm{~B}$ to estimate the metamorphic temperatures. One such traverse is shown in Fig. 5. The $\mathrm{Fe}^{2+} / \mathrm{Mg}$ partitioning coefficient between garnet and pyroxene and hence the metamorphic temperature was found to be highly variable and strongly dependent on the composition of the sodic pyroxene. In cases where jadeitic pyroxene is in contact with garnet, the meta- morphic temperature estimates, using the Ellis and Green (1979) calibration, are unrealistically high, in the range of $750-850{ }^{\circ} \mathrm{C}$ at a given pressure of 12 $\operatorname{kbar}\left(K_{\mathrm{D}}=7\right.$ to 10$)$. Where omphacitic pyroxene is in contact with garnet, the estimated temperature interval is narrower and more realistic, $470-560{ }^{\circ} \mathrm{C}$ (Fig. 5, $K_{\mathrm{D}}=28$ to 39 ). Because of the wide variation in the sodic pyroxene composition, metamorphic temperatures in this sample cannot be reliably estimated using the garnet-clinopyroxene geothermometer.

The Muttalip eclogite is a typical group $\mathrm{C}$ eclogite, characterized by close association with blueschists (Coleman et al., 1965). A large number of geothermometric studies exist for Group C eclogites, generally utilizing the Ellis and Green (1979) calibration of the garnet-clinopyroxene $\mathrm{Fe}-\mathrm{Mg}$ exchange equilibrium. 

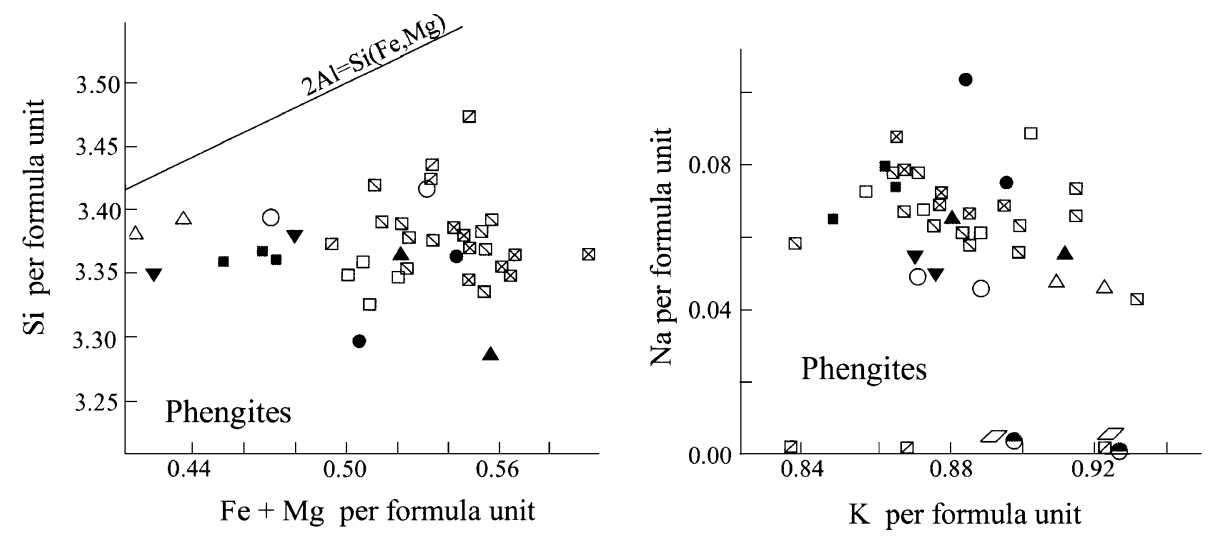

Fig. 7. Phengite compositions from the blueschist facies and greenschist facies Nilüfer unit. For symbols see Fig. 6.

Group C eclogites from California (e.g., Moore, 1984; Oh and Liou, 1990), Alaska (Patrick and Evans, 1989), Venezuela (Maresch and Abraham, 1981), Western Alps (e.g., Ernst and Dal Piaz, 1978), Cyclades (e.g., Schliestedt, 1986), Turkey (Okay, 1989b; Okay and Satır, 2000) and Oman (e.g., El-Shazly et al., 1990) give consistent temperature estimates of $500 \pm 50{ }^{\circ} \mathrm{C}$ at $10-15 \mathrm{kbar}$ pressure range. These temperature estimates are similar to those from omphacite-garnet contacts in the eclogite sample, and a temperature of $500 \pm 50{ }^{\circ} \mathrm{C}$ at $10-15$ kbar pressure range can be assumed for the Muttalip eclogite.

Sodic pyroxene is absent in the blueschist-metabasites studied, and a petrographic relationship between the eclogite and epidote-blueschists cannot be demonstrated. The inferred high-pressure mineral assemblage in the blueschist metabasites is sodic amphibole + chlorite + epidote + albite + phengite + quartz \pm garnet. Two pressure-sensitive equilibria in this assemblage are:

$$
\begin{aligned}
& \text { Chlorite }+ \text { albite }+ \text { quartz } \\
& =\text { paragonite }+ \text { sodic amphibole }+\mathrm{H}_{2} \mathrm{O}
\end{aligned}
$$

$$
\begin{aligned}
& \text { Chlorite }+ \text { albite }+ \text { quartz }+ \text { muscovite } \\
& =\text { paragonite }+ \text { sodic amphibole } \\
& \quad+\text { celadonite }+\mathrm{H}_{2} \mathrm{O}
\end{aligned}
$$

These equilibria are calculated with the THERMOCALC computer program of Powell et al. (1998) using the internally consistent thermodynamic data set of Holland and Powell (1998). The activities are calculated using the $A X$ program of Tim Holland, which uses the activity models outlined in Holland and Powell (1998). The mineral compositions used in the calculations are given in Table 2 . The reaction lines, marked as 1, 2 and 3 in Fig. 9, define a broad pressure field from 8.5 to $13 \mathrm{kbar}$ at $450{ }^{\circ} \mathrm{C}$ (Fig. 9). The biggest uncertainty in these calculations is the activity of paragonite. As paragonite is absent in the analysed metabasites, its activity was estimated from the paragonite component in phengite. The $X_{\mathrm{Na}}$ value $(\mathrm{Na} /(\mathrm{Na}+\mathrm{K}))$ of phengite in the critical assemblage has a restricted range of $0.05-0.08$ (Fig. 7), corresponding to paragonite activities of 0.4 to 0.7 . In highpressure rocks, phengites coexisting with paragonite have a maximum $X_{\mathrm{Na}}$ value of $\sim 0.10$ (Guidotti et al., 1994), suggesting that the estimated paragonite activities are not too different from the actual values. Furthermore, equilibrium (3) is rather insensitive to the exact value of the paragonite activity. For example, increasing the paragonite activity from 0.43 to 0.90 in the sample H132 increases the estimated pressure by less than $1 \mathrm{kbar}$. Apart from these equilibria, the phengite geobarometer of Massonne and Schreyer (1987) suggests minimum pressures of 10 kbar at $450{ }^{\circ} \mathrm{C}$ for the phengite compositions in the Eskişehir blueschists $(\sim 3.4 \mathrm{Si}$ per formula unit, cf. Fig. 7). 
Table 3

Representative mineral compositions from the Triassic metabasites and Cretaceous melange from northwest Turkey

\begin{tabular}{|c|c|c|c|c|c|c|c|c|c|c|c|c|c|c|}
\hline \multirow[t]{3}{*}{ Sample } & \multicolumn{3}{|c|}{ Barroisite-amphibolite } & \multirow{2}{*}{\multicolumn{3}{|c|}{$\begin{array}{l}\text { Actinolite-metabasite } \\
\text { E83 }\end{array}$}} & \multicolumn{8}{|c|}{ Cretaceous mafic volcanic rocks } \\
\hline & \multicolumn{2}{|l|}{ T39 } & \multirow{2}{*}{$\frac{\text { T82 }}{\text { Pheng. }}$} & & & & \multicolumn{2}{|l|}{ E12 } & \multicolumn{2}{|l|}{ E31 } & \multicolumn{2}{|l|}{ E51 } & \multicolumn{2}{|l|}{ E122 } \\
\hline & Barr. & Pheng. & & Actino. & Chlorite & Epidote & Laws. & Chlorite & $\mathrm{Na}-$ pyr. & Chlorite & $\mathrm{Na}$-pyr. & Chlorite & $\mathrm{Na}$-amp. & Chlorite \\
\hline $\mathrm{SiO}_{2}$ & 51.42 & 48.99 & 50.02 & 54.87 & 27.69 & 38.45 & 38.38 & 29.12 & 50.74 & 32.41 & 54.03 & 30.47 & 55.92 & 30.06 \\
\hline $\mathrm{TiO}_{2}$ & 0.17 & 0.25 & 0.12 & 0.00 & 0.00 & 0.00 & 0.37 & 0.00 & 0.54 & 0.00 & 0.42 & 0.00 & 0.00 & 0.48 \\
\hline $\mathrm{Al}_{2} \mathrm{O}_{3}$ & 6.50 & 26.48 & 26.02 & 1.73 & 20.05 & 25.35 & 31.99 & 17.93 & 5.00 & 14.98 & 4.61 & 15.02 & 5.90 & 15.89 \\
\hline $\mathrm{Cr}_{2} \mathrm{O}_{3}$ & 0.22 & 0.44 & 0.12 & 0.00 & 0.00 & 0.00 & 0.00 & 0.00 & 0.00 & 0.13 & 0.00 & 0.00 & 0.00 & 0.00 \\
\hline $\mathrm{FeO}$ & 14.88 & 3.64 & 3.51 & 11.05 & 22.20 & 10.77 & 1.26 & 19.47 & 20.35 & 17.75 & 20.76 & 21.79 & 19.94 & 23.99 \\
\hline $\mathrm{MgO}$ & 11.59 & 3.05 & 3.24 & 16.26 & 17.90 & 0.00 & 0.00 & 20.71 & 2.47 & 20.28 & 2.29 & 18.26 & 7.04 & 15.74 \\
\hline $\mathrm{MnO}$ & 0.00 & 0.00 & 0.00 & 0.22 & 0.27 & 0.00 & 0.00 & 0.23 & 0.14 & 0.22 & 0.00 & 0.32 & 0.14 & 0.59 \\
\hline $\mathrm{CaO}$ & 6.31 & 0.00 & 0.01 & 12.71 & 0.00 & 22.74 & 17.19 & 0.00 & 7.02 & 0.71 & 4.11 & 0.33 & 0.86 & 0.41 \\
\hline $\mathrm{Na}_{2} \mathrm{O}$ & 4.10 & 0.48 & 0.38 & 0.00 & 0.00 & 0.00 & 0.00 & 0.00 & 10.63 & 0.00 & 12.22 & 0.00 & 6.89 & 0.00 \\
\hline $\mathrm{K}_{2} \mathrm{O}$ & 0.19 & 10.07 & 9.98 & 0.00 & 0.00 & 0.00 & 0.00 & 0.00 & 0.00 & 0.11 & 0.00 & 0.00 & 0.00 & 0.09 \\
\hline Total & 95.38 & 93.40 & 93.40 & 96.84 & 88.11 & 97.31 & 89.19 & 87.46 & 96.89 & 86.59 & 98.44 & 86.19 & 96.69 & 87.25 \\
\hline
\end{tabular}

Mineral formula on the basis of

\begin{tabular}{|c|c|c|c|c|c|c|c|c|c|c|c|c|c|c|}
\hline & 23 oxy. & 11 oxy. & & 23 oxy. & 28 oxy. & 8 cat. & 5 cat. & 28 oxy. & 4 cat. & 28 oxy. & 4 cat. & 28 oxy. & 23 оxy. & 28 oxy. \\
\hline $\mathrm{Si}$ & 7.503 & 3.364 & 3.420 & 7.884 & 5.688 & 3.024 & 2.002 & 5.938 & 1.918 & 6.598 & 1.995 & 6.390 & 8.031 & 6.306 \\
\hline $\mathrm{Al}^{\mathrm{IV}}$ & 0.497 & 0.636 & 0.580 & 0.116 & 2.312 & & & 2.062 & 0.082 & 1.402 & 0.005 & 1.610 & & 1.694 \\
\hline $\mathrm{Al}^{\mathrm{VI}}$ & 0.621 & 1.508 & 1.517 & 0.176 & 2.543 & 2.350 & 1.967 & 2.249 & 0.139 & 2.193 & 0.194 & 2.100 & 0.999 & 2.236 \\
\hline $\mathrm{Ti}$ & 0.018 & 0.013 & 0.006 & 0.000 & 0.000 & 0.000 & 0.014 & 0.000 & 0.015 & 0.000 & 0.010 & 0.000 & 0.000 & 0.076 \\
\hline $\mathrm{Cr}$ & 0.026 & 0.024 & 0.007 & 0.000 & 0.000 & 0.000 & 0.000 & 0.000 & 0.000 & 0.000 & 0.000 & 0.000 & 0.000 & 0.000 \\
\hline $\mathrm{Fe}^{3+}$ & 0.602 & & & & & 0.709 & 0.055 & & 0.637 & & 0.643 & & 0.816 & \\
\hline $\mathrm{Fe}^{2+}$ & 1.214 & 0.209 & 0.201 & 1.328 & 3.815 & & & 3.321 & 0.005 & 3.022 & & 3.820 & 1.580 & 4.210 \\
\hline $\mathrm{Mg}$ & 2.522 & 0.312 & 0.330 & 3.481 & 5.480 & 0.000 & 0.000 & 6.294 & 0.139 & 6.153 & 0.123 & 5.710 & 1.507 & 4.922 \\
\hline $\mathrm{Mn}$ & 0.000 & 0.000 & 0.000 & 0.027 & 0.047 & 0.000 & 0.000 & 0.040 & 0.005 & 0.037 & 0.000 & 0.060 & 0.017 & 0.104 \\
\hline $\mathrm{Ca}$ & 1.001 & 0.000 & 0.000 & 1.956 & 0.000 & 1.917 & 0.961 & 0.000 & 0.284 & 0.154 & 0.160 & 0.070 & 0.132 & 0.092 \\
\hline $\mathrm{Na}$ & 1.176 & 0.063 & 0.051 & 0.000 & 0.000 & 0.000 & 0.000 & 0.000 & 0.776 & 0.000 & 0.870 & 0.000 & 1.918 & 0.000 \\
\hline $\mathrm{K}$ & 0.035 & 0.882 & 0.871 & 0.000 & 0.000 & 0.000 & 0.000 & 0.000 & 0.000 & 0.028 & 0.000 & 0.000 & 0.000 & 0.024 \\
\hline \multirow[t]{4}{*}{ Total } & 15.215 & 7.011 & 6.983 & 14.968 & 19.885 & 8.000 & 4.999 & 19.904 & 4.000 & 19.587 & 4.000 & 19.760 & 15.000 & 19.664 \\
\hline & & & & & & & $\mathrm{jd}$ & & 14 & & 19 & & & \\
\hline & & & & & & & aeg & & 64 & & 64 & & & \\
\hline & & & & & & & aug & & 22 & & 17 & & & \\
\hline
\end{tabular}

oxy., oxygens; cat., cations.

The absence of lawsonite in the blueschists indicates minimum temperatures of $410{ }^{\circ} \mathrm{C}$ at $11 \mathrm{kbar}$ on the basis of the reaction (Fig. 9):

Lawsonite + albite $=$ clinozoisite + paragonite

$$
+ \text { quartz }+\mathrm{H}_{2} \mathrm{O}
$$

In garnet-bearing epidote-blueschists, the appearance of sodic pyroxene, which marks the boundary of the eclogite facies, requires an increase in temperature (e.g. Ridley, 1984; Evans, 1990), and occurs at $\sim 500{ }^{\circ} \mathrm{C}$. Thus, a reasonable $P-T$ estimate for the
Muttalip epidote-blueschists is $11 \pm 2 \mathrm{kbar}$ and $450 \pm 50{ }^{\circ} \mathrm{C}$.

In the Eskişehir region, the transition from epidoteblueschist to epidote-amphibolites is characterized by the replacement of sodic amphibole by barroisite, and by an increase in the modal amounts of albite and chlorite in the rock. Because of the immiscibility between the sodic and sodic-calcic amphiboles (e.g., Toriumi, 1974; Brown, 1977; Ernst, 1979), the $X_{\mathrm{Ca}}$ $(\mathrm{Ca} /(\mathrm{Ca}+\mathrm{Na}))$ of the amphibole jumps from less than 0.06 in the sodic amphiboles to $\sim 0.5$ in the sodiccalcic amphiboles with a concomitant sharp increase in the tetrahedral aluminium. The stable mineral assemblage in the epidote-amphibolites is barroisite + ch- 


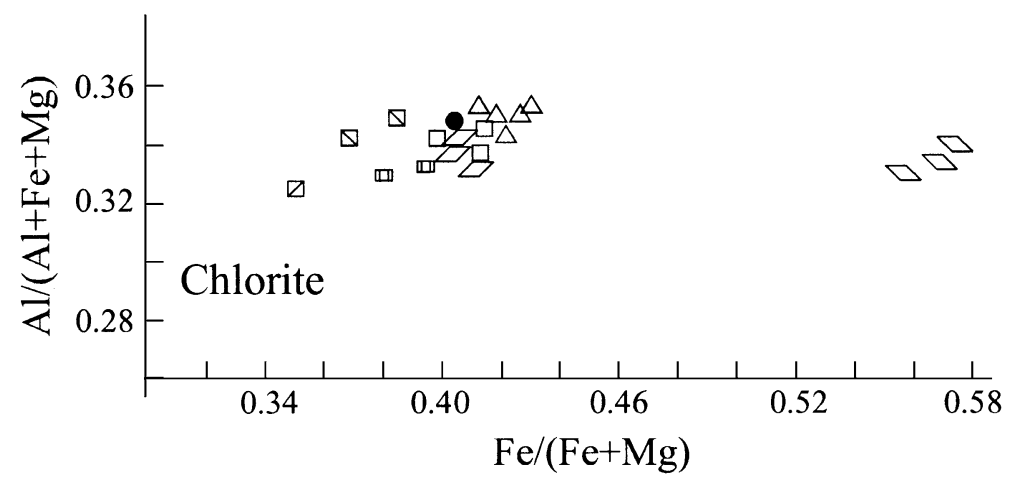

Fig. 8. Chlorite compositions from the blueschist facies and greenschist facies Nilüfer unit. For symbols see Fig. 6.

lorite + epidote + albite + phengite + quartz \pm garnet. A pressure-sensitive equilibrium in this assemblage is:

Glaucophane + clinozoisite + quartz $+\mathrm{H}_{2} \mathrm{O}$

$$
=\text { albite }+ \text { chlorite }+ \text { tremolite, }
$$

Reaction (5) is generally regarded as the main blueschist-to-greenschist facies reaction (Miyashiro and
Banno, 1958; Brown, 1974). It is experimentally investigated by Maruyama et al. (1986), which place the reaction between 7 and $8 \mathrm{kbar}$ in the $300-450{ }^{\circ} \mathrm{C}$ temperature range. Reactions (2) and (5) were calculated for the analysed barroisite-bearing epidoteamphibolites using the THERMOCALC program. These reactions indicate pressures of 7 to $9 \mathrm{kbar}$ at

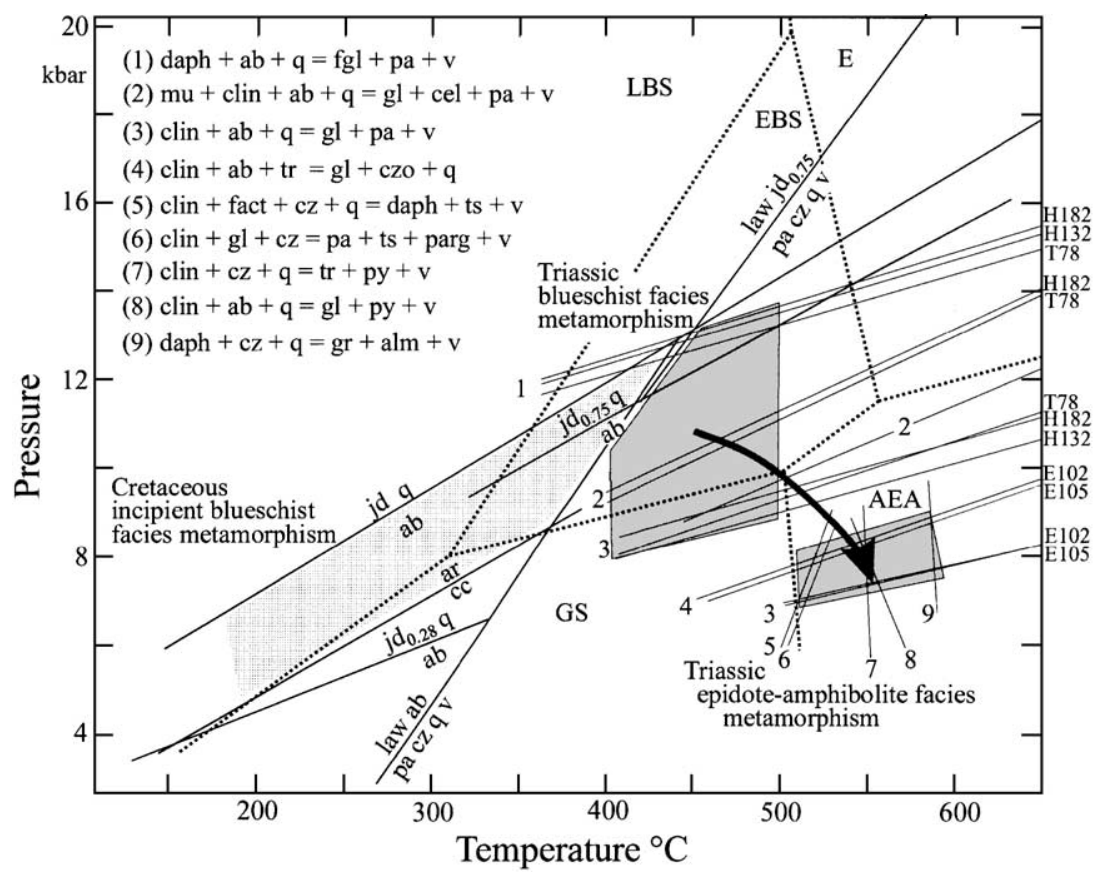

Fig. 9. Pressure-temperature diagram showing the estimated $P-T$ conditions of the Triassic and Cretaceous regional metamorphism in the Eskişehir area. All the reactions are calculated using the THERMOCALC program and the internally consistent data set of Holland and Powell (1998). The dotted lines, which delineate the facies boundaries, are after Evans (1990). The numbers on the right of the diagram refer to the samples for which the respective reactions are calculated. Abbreviations: ab, albite; ar, aragonite; cc, calcite; clin, clinochlore; cz, clinozoisite; daph, daphnite; fgl, ferroglaucophane; gl, glaucophane; jd, jadeite; ky, kyanite; law, lawsonite; mu, muscovite; pa, paragonite; tr, tremolite; q, quartz; v, $\mathrm{H}_{2} \mathrm{O}$; AEA, albite-epidote amphibolite; E, eclogite; EBS, epidote-blueschist; LBS, lawsonite-blueschist; GS, greenschist facies. 
$550{ }^{\circ} \mathrm{C}$ (Fig. 9). The temperatures in the epidoteamphibolites were estimated using relevant equilibria between amphibole, chlorite, garnet, albite and epidote in the analysed samples. These equilibria, shown on Fig. 9, indicate a temperature range of 510 to $580{ }^{\circ} \mathrm{C}$ at $8 \mathrm{kbar}$ for the barroisite-bearing epidote-amphibolites. A reasonable estimate for the $P-T$ conditions of the albite-epidote facies metamorphism in the Muttalip thrust sheet is $540 \pm 40{ }^{\circ} \mathrm{C}$ and $8 \pm 1$ kbar.

The transition from the epidote-blueschists to epidote-amphibolites involves an increase in temperature and decrease in pressure. The main blueschistto-greenschist transformation reaction (Eq. (5)) requires $\mathrm{H}_{2} \mathrm{O}$-rich fluids for its completion (Miyashiro and Banno, 1958; Brown, 1974; Maruyama et al., 1986). The close field association of epidote-blueschists and epidote-amphibolites is probably due to irregular influx of $\mathrm{H}_{2} \mathrm{O}$-rich fluids, as has been shown in several other blueschist-greenschist terrains (e.g., Schliested and Matthews, 1987; Bröcker, 1990; Barrientos and Selverstone, 1993; El-Shazly et al., 1997).

\subsection{Greenschist facies Nilüfer unit}

The typical mineral assemblage in the metabasites in the Avlamıs thrust sheet is actinolite/hornblende+
Table 4

Estimated mineral modes of the analysed mafic rocks from the Dağküplü mélange

\begin{tabular}{llllll}
\hline & E12 & E31 & E51 & E77 & E122 \\
\hline Albite & 12 & 37 & 47 & 34 & 25 \\
Chlorite & 13 & 26 & 22 & 10 & 28 \\
Lawsonite & 31 & - & - & 6 & 11 \\
Sodic pyroxene & 1 & 22 & 5 & 2 & - \\
Sodic amphibole & tr. & - & - & 9 & 27 \\
Calcic amphibole & - & - & - & 33 & - \\
Carbonate & tr. & 7 arag & 3 & - & - \\
Epidote & - & - & - & tr. & - \\
Quartz & 4 & - & - & - & - \\
White mica & - & - & - & tr. & - \\
Pumpellyite & - & - & - & tr. & - \\
Leucoxene & 9 & 8 & 10 & 6 & 7 \\
Opaque & 3 & - & - & - & 2 py \\
Magmatic augite & 27 & - & 13 & - & - \\
\hline
\end{tabular}

tr., $<0.5$; arag, aragonite; py, pyrite.

albite + epidote + chlorite + sphene \pm quartz. Garnet and barroisite are conspicuously absent in the metabasic rocks of the Avlamıs thrust sheet. The Na content of the calcic amphibole in the mineral assemblage above, with additional iron oxide, has been used as a geobarometer (Brown, 1977). The very low Na contents of calcic amphiboles in the metabasites of the

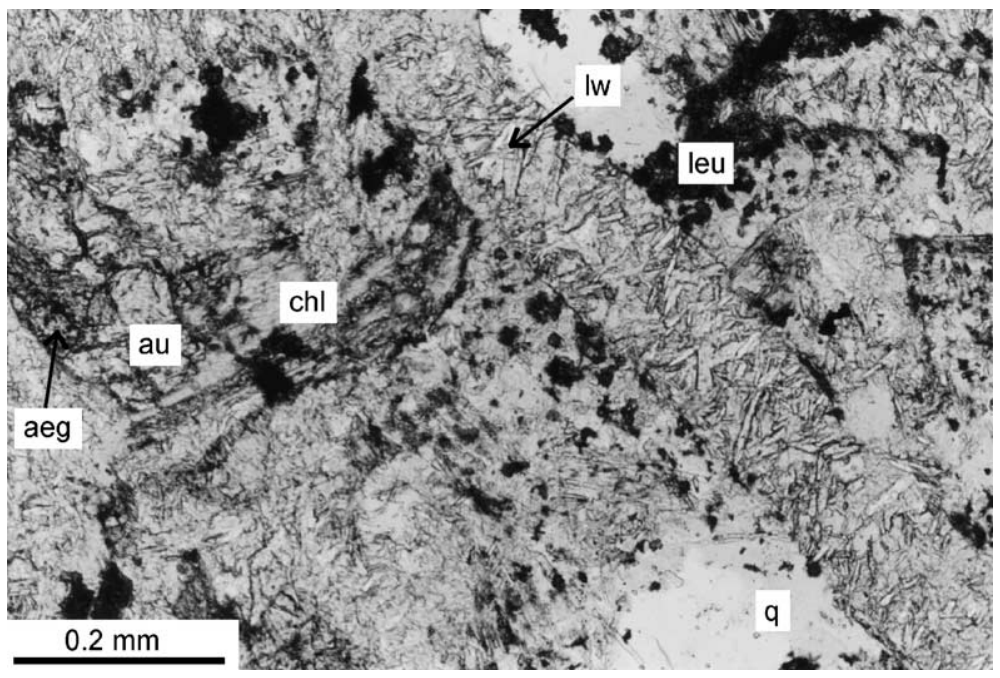

Fig. 10. Photomicrograph of an incipiently metamorphosed diabase from the Dağküplü mélange. The igneous plagioclase is replaced by an intergrowth of lawsonite (law) and albite. Magmatic augite (au) shows partial replacement by an aegerine-rich sodic pyroxene (aeg). Quartz (q), chlorite (chl) and sphene (leu) are the other minerals. Sample E12, plane polarised light. 
Avlamış thrust sheet indicate pressures of less than 4 kbar (Table 3).

\subsection{Incipient blueschist metamorphism in the Dăg- küplü mélange}

The Cretaceous accretionary mélange north of Eskişehir has undergone an incipient blueschist facies metamorphism characterized by the sporadic occurrence of lawsonite, sodic pyroxene, sodic amphibole and aragonite in mafic volcanic rocks. Igneous textures and magmatic augite are commonly preserved in the mafic volcanic rocks, which consist mainly of albite, chlorite, magmatic augite and sphene (Table 4). High-pressure metamorphic phases have developed as replacement minerals or occur in veins and amygdales in mafic volcanic rocks. Five mafic volcanic rocks showing incipient blueschist metamorphism were analysed by the electron microprobe. Sodic pyroxene occurs as rims or veins in magmatic augite and is of chloromelanite to aegerine composition with a maximum jadeite content of 0.28 (Fig. 11). Lawsonite is found as aggregates of small $(<0.03 \mathrm{~mm})$ prismatic grains, which, along with albite, have pseudomorphed plagioclase (Fig. 10). It has a relatively high ferric content (up to $2.5 \mathrm{wt} . \%$ ), a typical feature of lowtemperature lawsonite (Table 3). In few samples, sodic amphibole forms slender crystals in chlorite-rich patches. Aragonite, determined from its characteristic lamellar twinning, occurs in the amygdales and in veins in the mafic volcanic rocks. It forms coarse crystals measuring several millimetres across. Chlorites from the Dağküplü mélange have lower $\mathrm{Al}$ and higher Si contents than those from the Nilüfer unit (Fig. 11, Table 3). The presence of albite, aragonite and lawsonite indicates metamorphic conditions of 6
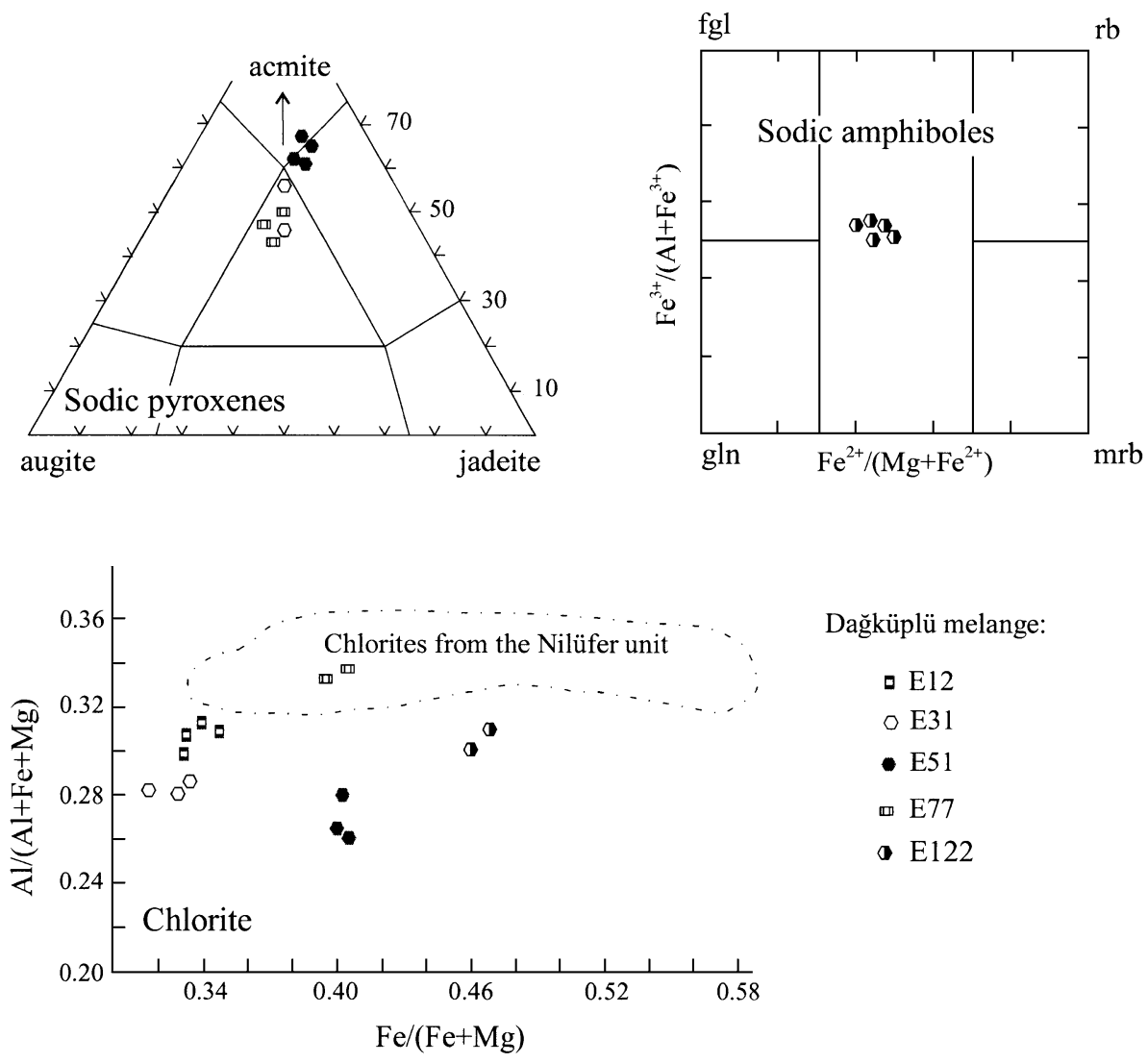

Fig. 11. Sodic pyroxene, sodic amphibole and chlorite compositions from the incipiently metamorphosed mafic volcanic rocks of the Upper Cretaceous Dağküplü mélange. 
to $8 \mathrm{kbar}$, and 200 to $380{ }^{\circ} \mathrm{C}$ for the Dağküplü mélange (Fig. 9). The lack of recrystallisation suggests temperatures in the lower end of this range. These rocks are similar to those described from farther southwest in the Tavşanlı Zone (Okay, 1982).

\section{Geochronology}

Phengite and amphibole from two metabasites from the Muttalip thrust sheet were dated with the ${ }^{40} \mathrm{Ar} /{ }^{39} \mathrm{Ar}$ step-heating laser-probe method (e.g., Dalrymple, 1989; Monié et al., 1997). In addition, bulk separates of phengite from a third metabasite and of biotite from the Sögüt granitoid were analysed using a classical high-frequency argon release system (e.g., McDougall and Harrison, 1988). Isotopic data are reported in Table 5. Sodic amphibole, barroisite and phengite compositions from the dated specimens are given in Tables 2 and 3.

Sample T78 is a blueschist with the mineral assemblage of glaucophane + epidote + albite + chlorite + phengite + calcite (Fig. 4b). Some of the glaucophane grains have narrow rims of barroisite. One phengite grain was progressively degassed and produced a good plateau of $203.7 \pm 2.6$ Ma for nearly $100 \%$ of the argon released (Fig. 12a). The age defined by the ${ }^{36} \mathrm{Ar} /{ }^{40} \mathrm{Ar}$ vs. ${ }^{39} \mathrm{Ar} /{ }^{40} \mathrm{Ar}$ isochron plot is similar to the plateau age (Table 5). A single glaucophane grain from the same sample yielded a plateau of $204.8 \pm 4.7 \mathrm{Ma}$ with eight steps representing $98 \%$ of the argon released (Fig. 12b). The isochron plot indicates a younger intercept age of $192.0 \pm 3.4 \mathrm{Ma}$ with a non-atmospheric initial ${ }^{40} \mathrm{Ar} /{ }^{36} \mathrm{Ar}$ ratio, which points to a minor excess argon contamination (Table 5). For this amphibole, the microprobe analyses reveal a very low $\mathrm{K}_{2} \mathrm{O}$ content
(0.03\%), which, according to Sisson and Onstott (1986), could suggest that argon has been mainly released from microscopic inclusions of phengite in glaucophane. Nonetheless, these inclusions have the same age as the matrix phengite.

Samples T39 and T82 are barroisite-bearing epidote-amphibolites consisting of barroisite, epidote, albite, phengite and calcite (Table 1). A single phengite grain from T39 gave a plateau age of $214.9 \pm 2$ Ma related to $96 \%$ of the argon released (Fig. 12c), and three barroisite grains $\left(\mathrm{K}_{2} \mathrm{O}=0.2 \%\right)$ from the same sample displayed a partially disturbed convex age spectrum with a plateau age of $209.7 \pm 4.2 \mathrm{Ma}$ for $86 \%$ of argon (Fig. 12d). The isochron date of this sample is $207.1 \pm 3.6 \mathrm{Ma}$ with an initial argon ratio close to the present-day value of 295.5 (Table 5). As in the case with glaucophane from the sample T78, strong variations are observed with the ${ }^{37} \mathrm{Ar} /{ }^{39} \mathrm{Ar}$ ratios during progressive argon outgassing of the barroisite, which suggest that both of the dated amphiboles are compositionally heterogeneous. Phengite bulk separate from sample T82 was analysed using a classical high-frequency argon release system (e.g., McDougall and Harrison, 1988), which gave a plateau age of $203.7 \pm 3.4 \mathrm{Ma}$ for $97 \%$ of the ${ }^{39} \mathrm{Ar}$ released (Fig. 12e) and a similar isochron date.

The phengite and amphibole ages of 204-215 Ma from the blueschists and epidote-amphibolites of the Muttalip thrust sheet correspond within errors to the Triassic-Jurassic boundary (205.7 $\pm 4.0 \mathrm{Ma}$, Gradstein et al., 1994). The Late Triassic isotopic ages are compatible with the biostratigraphic constraints on the age of the regional metamorphism, provided by the Mid-Triassic conodonts in the Nilüfer Unit (Early Ladinian, $234 \mathrm{Ma}$, Kaya and Mostler, 1992) and the Sinemurian age of the base of the overlying Jurassic sequence (202 Ma, Alkaya, 1981). Furthermore, they

Table 5

Isotope data from the metabasites of the Muttalip thrust sheet and from the Söğüt granite

\begin{tabular}{|c|c|c|c|c|c|c|c|}
\hline Sample & Rock type & Mineral & Total age (Ma) & Plateau (Ma) & Isochron & ${ }^{40} \mathrm{Ar} /{ }^{36} \mathrm{Ar}$ & MSWD \\
\hline \multirow[t]{2}{*}{$\mathrm{T} 78$} & Blueschist metabasite & Phengite (s.g.) & $203.6 \pm 2.6$ & $203.7 \pm 2.6$ & $203.9 \pm 2.6$ & $254 \pm 49$ & 1.41 \\
\hline & & Glaucophane (s.g.) & $206.8 \pm 5.4$ & $204.8 \pm 4.7$ & $192.0 \pm 3.4$ & $378 \pm 79$ & 0.12 \\
\hline \multirow[t]{2}{*}{ T39 } & Barroisite-amphibolite & Phengite (s.g.) & $214.1 \pm 2.7$ & $214.9 \pm 2.7$ & $214.0 \pm 2.8$ & $571 \pm 335$ & 1.15 \\
\hline & & Barroisite (s.g.) & $207.8 \pm 4.4$ & $209.7 \pm 4.2$ & $207.1 \pm 3.6$ & $320 \pm 30$ & 0.23 \\
\hline T82 & Barroisite-amphibolite & Phengite (b.s.) & $203.1 \pm 3.4$ & $203.7 \pm 3.4$ & $204.7 \pm 3.4$ & $279 \pm 22$ & 0.82 \\
\hline T69 & Granite & Biotite (b.s.) & $283.3 \pm 4.7$ & $290.0 \pm 4.8$ & $291.4 \pm 4.9$ & $283 \pm 12$ & 2.66 \\
\hline
\end{tabular}

s.g., single grain; b.s., bulk separate. 

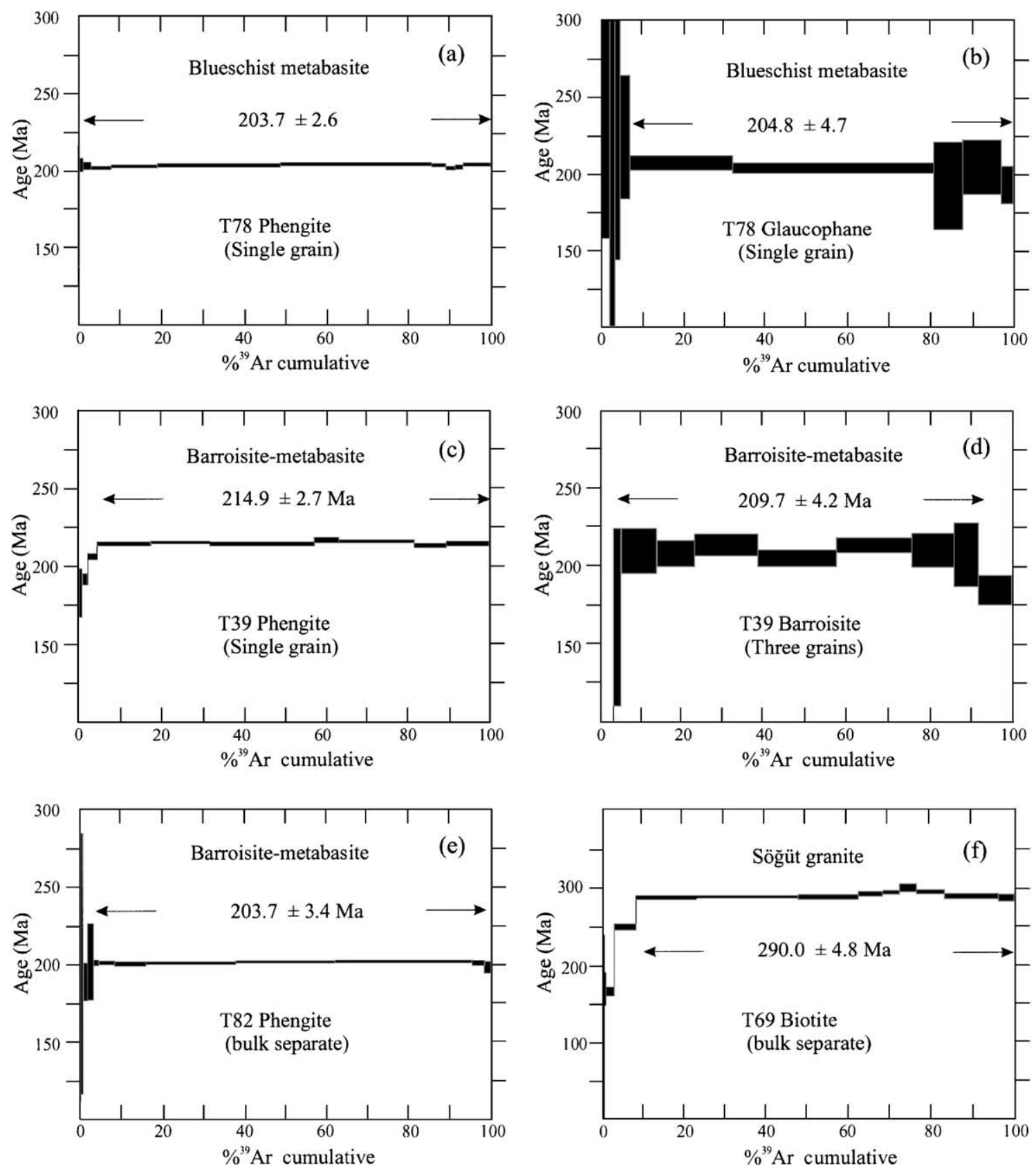

Fig. 12. Ar/Ar isotopic ages from the Nilüfer unit and the Sögüt granitoid from north of Eskişehir.

are very similar to those found in the Bandirma eclogite (203 to 208 Ma, Okay and Monié, 1997), $210 \mathrm{~km}$ farther west. This consistency of geochronological and biostratigraphic constraints suggests that none of the dated minerals incorporated excess argon during crystallisation under high pressure conditions or later during some retrogressive event. Incorporation of excess argon has been shown to be a frequent problem in high-pressure rocks, resulting in ages older than those obtained using more robust geochronolog- 
ical methods (e.g. Arnaud and Kelley, 1995; Scaillet, 1996; Sherlock et al., 1999; Giorgis et al., 2000; ElShazly et al., 2001). The presence of this excess component generally results from the degassing and destabilization of ancient minerals and argon trapping in the newly formed high-pressure minerals due to the limited mobility of fluids in this type of metamorphic environment (e.g., Philippot and Rumble, 2000). The amount of trapped excess argon is dependent on the solubility of argon within the different minerals as well as on the very local variations of the partial argon pressure and initial ${ }^{40} \mathrm{Ar} /{ }^{36} \mathrm{Ar}$ ratio. As a consequence, the main signature of excess argon contamination is the extent of age variations within single grains, between grains and between rocks that underwent similar metamorphic conditions. The consistent pattern of our ${ }^{40} \mathrm{Ar} /{ }^{39} \mathrm{Ar}$ ages argues against a strong contamination by excess argon of the dated micas and amphiboles. These ages can be interpreted to record the time when the various chronometers started to retain argon under their specific closure temperature.

Closure temperature $\left(T_{\mathrm{c}}\right)$ of $\mathrm{Ar}$ in muscovite has been generally assumed to be in the range of 350-400 ${ }^{\circ} \mathrm{C}$ or slightly above $400{ }^{\circ} \mathrm{C}$ according to some recent observations (e.g., Hames and Bowring, 1994; Kirschner et al., 1996). For the phengite group, there is still a debate on the true value of $T_{\mathrm{c}}$, due to the lack of experimental diffusion data and of some conflicting and controversial results obtained in many high-pressure belts that would indicate that the diffusion of argon in phengite is dependent on a large variety of intrinsic and extrinsic parameters (chemical composition, pressure effect, cooling rate, grain size, deformation, fluid mobility, etc.) whose respective role remains to be investigated (e.g. Monié and Chopin, 1991; Scaillet et al., 1992; Giorgis et al., 2000). Moreover, recent studies have shown that phengite can survive a subsequent amphibolite metamorphism without argon loss despite a temperature that exceeded $600{ }^{\circ} \mathrm{C}$ (Di Vincenzo et al., 2001). Therefore, it seems hazardous to attribute a precise Tc to the phengites dated during this study. However, because the peak temperatures in the Karadere thrust sheet were $\sim 540{ }^{\circ} \mathrm{C}$, and given the relatively high cooling rates prevailing during the exhumation of highpressure rocks (e.g. Gebauer, 1999), it is likely that the phengite ages record a cooling stage soon after the Triassic regional metamorphism. The age variation from 215 to 204 Ma shown by these phengites is interpreted as the consequence of the metamorphic evolution from epidote-blueschists to amphibolites.

A biotite bulk separate from a sample of the Söğüt granitoid was dated using $\mathrm{Ar} / \mathrm{Ar}$ stepwise heating method (Fig. 12f). It gives a partially discordant age spectrum, characterized by argon loss at low experimental temperature and a small bump at intermediate temperature (e.g. Ruffet et al., 1991 for a possible explanation of this shape). An integrated age of $290 \pm 4 \mathrm{Ma}$ has been calculated over $90 \%$ of the argon released, which corresponds to the Carboniferous-Permian boundary, and is slightly older than an early K-Ar age from the Söğüt granitoid (272 Ma, Çoğulu and Krummenacher, 1967).

\section{Discussion and conclusions}

Upper Triassic high-pressure metamorphic rocks in northwest Turkey occur within an Eocene thrust sheet immediately north of the Izmir-Ankara suture. They include eclogite, blueschist and epidote-amphibolite. Eclogite is found only in a single locality, and it is not clear whether it represents an exotic block or is a relic from an early regional eclogite facies metamorphism. In contrast, there is ample evidence for petrographic transition from epidote-blueschists to barroisite-bearing epidote-amphibolites caused by an increase in temperature and decrease in pressure (Fig. 9). This type of clockwise $P-T-t$ path is classically interpreted as the result of tectonic thickening followed by uplift and erosion (e.g., England and Richardson, 1977).

The Upper Triassic high-pressure metamorphic rocks in northwest Turkey constitute part of a much larger Triassic mafic magmatic complex, the Nilüfer unit, which has been variously interpreted as a former oceanic island (Pickett and Robertson, 1996), an oceanic plateau (Okay, 2000) or an ensimatic forearc sequence (Göncüoğlu et al., 2000). These oceanic edifices were accreted during the latest Triassic to the active continental margin of Laurasia (Fig. 13b), represented at present by the Upper Palaeozoic granitoids within the Tertiary fold and thrust belt. The latest Triassic Cimmeride orogeny in the northern Turkey was probably caused by the collision and partial accretion of the Nilüfer oceanic plateau to the southern 
S

Paleo-Tethyan subduction

Sakarya Zone N

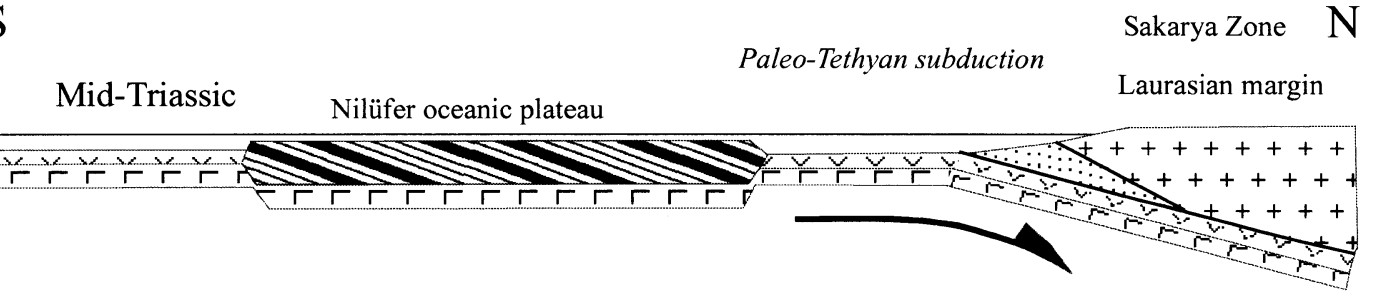

Clastic wedge fed from the

Hercynian granitic basement

(b)

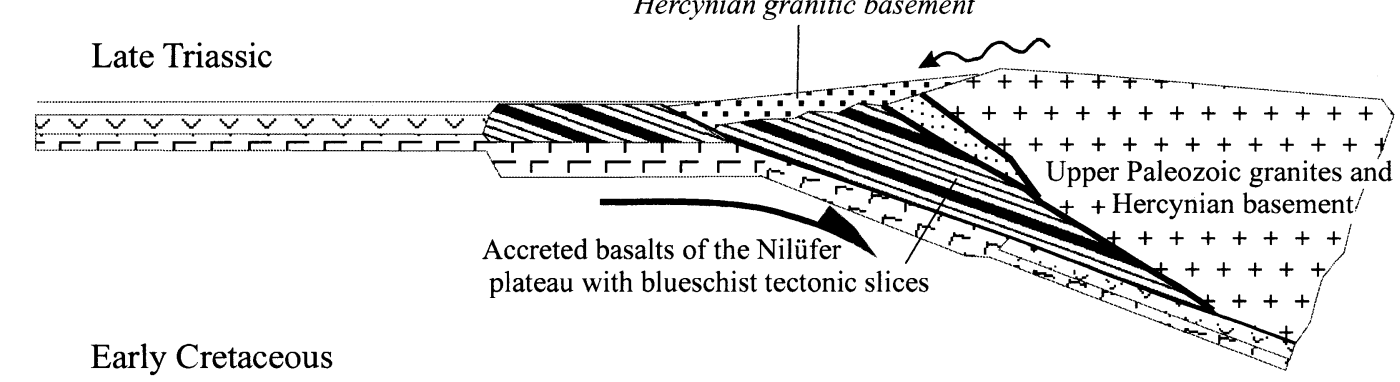

Early Cretaceous

Jurassic-Lower Cretaceous

Passive margin development cover sediments

(c)

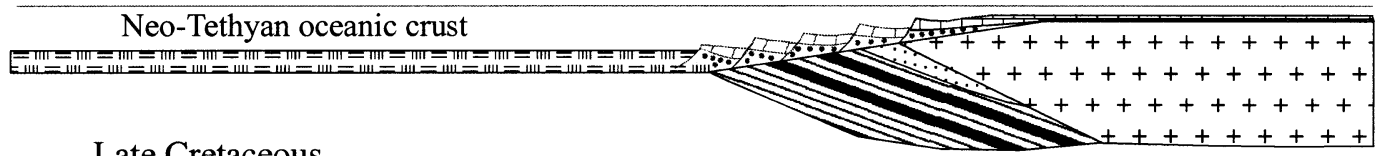

\section{Late Cretaceous}

Neo-Tethyan subduction

Anatolide-Tauride Block

Neo-Tethyan

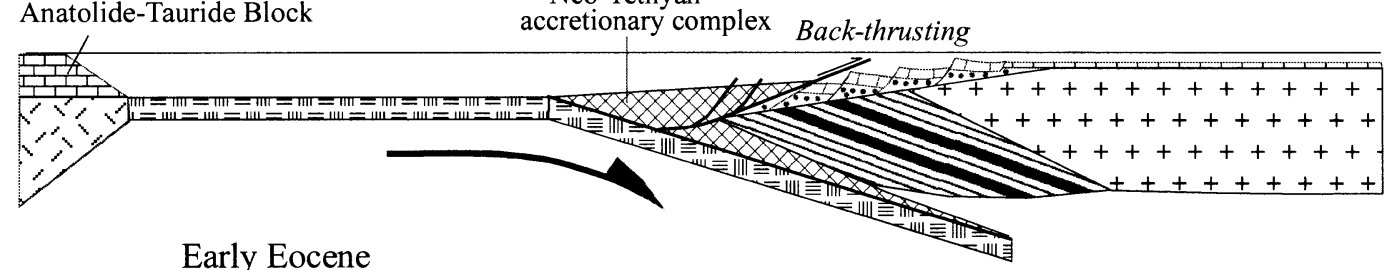

Early Eocene

Continental collision

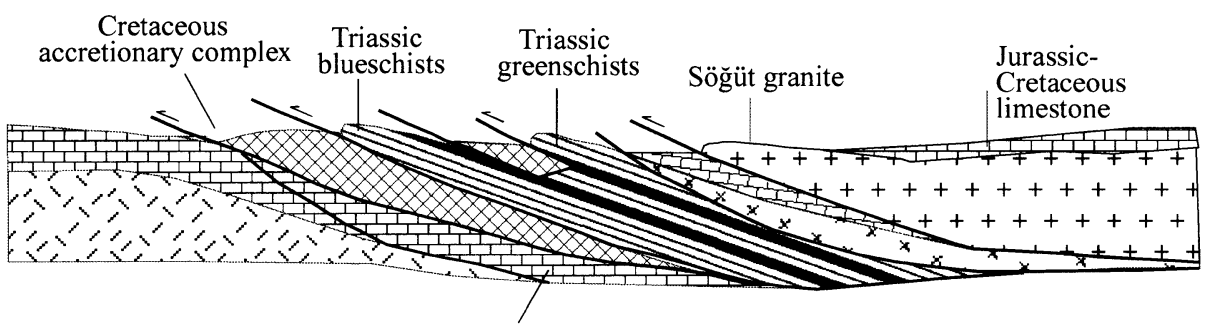

Cretaceous blueschists

Fig. 13. Schematic cross sections illustrating Triassic to Eocene tectonic evolution of the southern margin of Laurasia in the northwest Turkish transect. See text for details.

margin of the Laurasia (Okay, 2000). The collision resulted in the uplift of the Laurasian margin, and a thick wedge of arkosic clastics was deposited on the accreted slices of the Nilüfer unit, forming a Late Triassic fore-arc basin (Fig. 13b). A thin sliver of these Upper Triassic arkosic sandstones is present between 
the Muttalip and Avlamıs thrust sheets (Fig. 3). The Cimmeride orogeny in the Pontides involved deformation and metamorphism of the Nilüfer unit, as well as the overlying Late Triassic clastic rocks. It was a short-lived orogeny and was completed by the Early Jurassic (Sinemurian), when continental sandstones and conglomerates were deposited unconformably on the Nilüfer unit, on the Upper Triassic sandstones and on the Upper Palaeozoic granites throughout the Sakarya Zone. Although the Early Jurassic unconformity is not observed in the area studied, field relations from nearby areas indicate that the Triassic blueschists and eclogites must have been at or near the surface in the Early Jurassic, which is corroborated by the isotopic data. Northward subduction apparently ceased with the Cimmeride orogeny, and during the Jurassic and Early Cretaceous, the southern margin of the Sakarya Zone was the site of passive margin sedimentation (Fig. 13c). The Triassic blueschists and eclogites, as well as the Upper Palaeozoic granitoids, formed the basement of a Jurassic to Cretaceous sedimentary sequence (Fig. 2). Renewed subduction under the Sakarya Zone started in the Late Cretaceous, as indicated by Senonian arc-magmatism along the Black Sea coast (Şengör and Yılmaz, 1981; Okay and Şahintürk, 1997), and an accretionary complex was built up at its leading margin, represented by the Dağküplü mélange in the region studied. During the early Senonian, the accretionary complex was backthrust northward over the Sakarya Zone (Fig. 13d). Northward emplacement of the accretionary complex during the early Senonian (Cenomanian-Turonian) is described from the Eastern Pontides (Bergougnan, 1976; Okay and aahintürk, 1997) and from the Lesser Caucasus (Knipper, 1980), and may have extended as far west as the Eskişehir region. Senonian was also the period when the northern margin of the AnatolideTauride Block was subducted under the Tethyan oceanic lithosphere leading to the Campanian blueschist facies metamorphism (Okay, 1986; Sherlock et al., 1999). The subsequent Eocene continental collision between the Sakarya Zone and the Anatolide-Tauride Block was marked in the Eskişehir region by southvergent thrusting, which again brought the Triassic blueschists to the surface (Fig. 13e). The combination of Senonian north-vergent back-thrusting and Eocene south-vergent thrusting led to the imbrication of the Triassic blueschists and Upper Cretaceous accretion- ary complex. A similar situation is reported from the Eastern Pontides, where Upper Cretaceous accretionary mélange forms tectonic wedges in the Nilüfer unit (Bozkurt et al., 1997).

The present-day contacts of the Triassic blueschist-eclogite unit are Eocene thrusts, implying that it was originally a larger tectonic unit. As in the Bandirma region of northwest Turkey (Okay and Monié, 1997), the Triassic blueschists north of Eskiş ehir probably formed a large tectonic slice within the greenschist facies metabasites (Fig. 2).

The close spatial association of the Upper Triassic and Upper Cretaceous accretionary complexes and blueschists along the İzmir-Ankara suture suggests that the suture represents a long-lived continental margin from at least Late Palaeozoic to early Tertiary. It was a plate boundary during two intervals: Late Triassic and Senonian-early Tertiary. It is remarkable that Precambrian (Candan et al., 2001), Triassic (Okay and Monié, 1997; this study), Cretaceous (Sherlock et al., 1999), Eocene (e.g., Okrusch and Bröcker, 1990; Oberhänsli et al., 1998) and Oligo-Miocene (Seidel et al., 1982) blueschists and eclogites occur within a relatively small area in the Aegean region. This reflects the long-standing position of the region at an active continental margin bordering the Tethyan oceans.

\section{Acknowledgements}

We thank Remzi Akkök for help during the fieldwork, Gilles Drouet-Malewitch for assistance at the microprobe, Boris Natalin for reviewing an early draft of the manuscript, Aley El-Shazly and Patrick O'Brien for detailed constructive reviews.

\section{References}

Alkaya, F., 1981. Ammonite zones in the Bilecik region (in Turkish). Istanb. Yerbilim. 1, 297-302.

Altıner, D., Koçyigit, A., Farinacci, A., Nicosia, U., Conti, M.A., 1991. Jurassic Lower Cretaceous stratigraphy and paleogeographic evolution of the southern part of north-western Anatolia. Geol. Rom. 28, 13-80.

Altınl, I.E., 1975. Geology of the central Sakarya region. Proceedings of the Geological Congress for the 50th Anniversary of the Turkish Republic, Ankara, 159-190.

Arnaud, N.O., Kelley, S.P., 1995. Evidence for excess argon during 
high pressure metamorphism in the Dora Maira Massif (western Alps, Italy), using an ultra-violet laser ablation microprobe ${ }^{40} \mathrm{Ar}-{ }^{39} \mathrm{Ar}$ technique. Contrib. Mineral. Petrol. 121, 1-11.

Asutay, H.J., Küçükayman, A., Gözler, M.Z., 1989. Structural setting stratigraphy and petrography of the cumulates of the Dağküplü ophiolite complex (north of Eskiş ehir) (in Turkish). Maden Tetkik Arama Derg. 109, 1-8.

Barrientos, X., Selverstone, J., 1993. Infiltration vs. thermal overprinting of epidote blueschists, Ile de Groix, France. Geology $21,69-72$.

Bergougnan, H., 1976. Structure de la Chaine pontique dans le haut-Kelkit (Nord-Est de 1'Anatolie). Bull. Soc. Géol. Fr. 13, 675-686.

Bozkurt, E., Holdsworth, B.K., Koçyiğit, A., 1997. Implications of Jurassic chert identified in the Tokat Complex, northern Turkey. Geol. Mag. 134, 91-97.

Bröcker, M., 1990. Blueschist-to-greenschist transition in metabasites from Tinos Island, Cyclades, Greece: compositional control or fluid infiltration? Lithos 25, 25-39.

Brown, E.H., 1974. Comparison of the mineralogy and phase relations of blueschists from the North Cascades, Washington and greenschists from Otago, New Zealand. Bull. Geol. Soc. Am. $85,333-344$.

Brown, E.H., 1977. The crossite content of $\mathrm{Ca}$-amphibole as a guide to pressure of metamorphism. J. Petrol. 18, 53-72.

Candan, O., Dora, O.Ö., Oberhänsli, R., Çetinkaplan, M., Partzsch, J.H., Warkus, F.C., Dürr, S., 2001. Pan-African high-pressure metamorphism in the Precambrian basement of the Menderes Massif, western Anatolia, Turkey. Int. J. Earth Sci. (Geol. Rundsch.) 89, $793-807$.

Çoğulu, E., Krummenacher, D., 1967. Problèmes géochronométriques dans le partie NW de l'Anatolie Centrale (Turquie). Schweiz. Mineral. Petrogr. Mitt. 47, 825-831.

Coleman, R.G., Lee, D.E., Beatty, L.B., Brannock, W.W., 1965. Eclogites and eclogites: their differences and similarities. Geol. Soc. Amer. Bull. 76, 483-508.

Dalrymple, G.B., 1989. The GML continuous laser system for ${ }^{40} \mathrm{Ar} /{ }^{39} \mathrm{Ar}$ dating: description and performance characteristics. In: Shanks, W.C., Criss, R.E. (Eds.), New Frontiers in Stable Isotopic Research: Laser Probes, Ion Probes and Small Sample Analysis. US Geological Survey Bulletin, vol. 1890, pp. 89-96.

Di Vincenzo, G., Ghiribelli, B., Giorgetti, G., Palmeri, R., 2001. Evidence of a close link between petrology and isotope records: constraints from SEM, EMP, TEM and in situ ${ }^{40} \mathrm{Ar}-{ }^{39} \mathrm{Ar}$ laser analyses on multiple generations of white micas (Lanterman Range, Antarctica). Earth Planet. Sci. Lett. 192, 389-405.

Ellis, D.J., Green, D.H., 1979. An experimental study of the effect of $\mathrm{Ca}$ upon garnet-clinopyroxene $\mathrm{Fe}-\mathrm{Mg}$ exchange equilibria. Contrib. Mineral. Petrol. 71, 13-22.

El-Shazly, A.E., Coleman, R.G., Liou, J.G., 1990. Eclogites and blueschists from northeastern Oman: petrology and $P-T$ evolution. J. Petrol. 31, 629-666.

El-Shazly, A.K., Worthing, M.A., Liou, J.G., 1997. Interlayered eclogites, blueschists and epidote amphibolites from NE Oman: a record of protolith compositional control and limited fluid infiltration. J. Petrol. 38, 1461-1487.

El-Shazly, A.K., Bröcker, M., Hacker, B., Calvert, A., 2001. For- mation and exhumation of blueschists and eclogites from $\mathrm{NE}$ Oman: new perspectives from $\mathrm{Rb}-\mathrm{Sr}$ and ${ }^{40} \mathrm{Ar} /{ }^{39} \mathrm{Ar}$ dating. J. Metamorph. Geol. 19, 233-248.

England, P.C., Richardson, S.W., 1977. The influence of erosion upon the mineral facies of rocks from different metamorphic environments. J. Geol. Soc. (Lond.) 134, 201-213.

Ernst, W.G., 1979. Coexisting sodic and calcic amphiboles from high-pressure metamorphic belts and the stability of barroisitic amphibole. Mineral. Mag. 43, 269-278.

Ernst, W.G., Dal Piaz, G.V., 1978. Mineral parageneses of eclogitic rocks and related mafic schists of the Piemonte ophiolite nappe. Breuil-St. Jacques area, Italian Western Alps. Am. Mineral. 63, 621-640.

Evans, B.W., 1990. Phase relations of epidote blueschists. Lithos 25, 3-23.

Gebauer, D., 1999. Alpine geochronology of the Central and Western Alps: new constraints for a complex geodynamic evolution. Schweiz. Mineral. Petrogr. Mitt. 79, 191-208.

Genç, S.C., Yılmaz, Y., 1995. Evolution of the Triassic continental margin northwest Anatolia. Tectonophysics 243, 193-207.

Giorgis, D., Cosca, M., Li, S., 2000. Distribution and significance of extraneous argon in UHP eclogite (Sulu terrain, China): insight from in situ ${ }^{40} \mathrm{Ar} /{ }^{39} \mathrm{Ar}$ UV-laser ablation analysis. Earth Planet. Sci. Lett. 181, 605-615.

Göncüoğlu, M.C., Turhan, N., Şentürk, K., Özcan, A., Uysal, Ş., Yalınız, M.K., 2000. A geotraverse across northwestern Turkey: tectonic units of the Central Sakarya region and their tectonic evolution. In: Bozkurt, E., Winchester, J.A., Piper, J.A.D. (Eds.), Tectonics and Magmatism in Turkey and the Surrounding Area. Geological Society London Special Publications, vol. 173, pp. $139-162$.

Göncüoğlu, M.C., Tekin, U.K., Turhan, N., 2001. Late Carnian radiolarite within the Upper Cretaceous Central Sakarya ophiolitic mélange, NW Anatolia (in Turkish). Proceedings 54th Geol. Congress Turkey. Geol. Soc. Turkey, Ankara, pp. 54-56.

Gradstein, F.M., Agterberg, F.P., Ogg, J.G., Hardenbol, J. van, Veen, P., Thierry, J., Huang, Z., 1994. A Mesozoic time scale. J. Geophys. Res. 99, 24051-24074.

Guidotti, C.V., Sassi, F.P., Sassi, R., Blencoe, J.G., 1994. The effect of ferromagnesian components on the paragonite-muscovite solvus: a semiquantitative analysis based on chemical data for natural paragonite-muscovite pairs. J. Metamorph. Geol. 12, $779-788$.

Hames, W.E., Bowring, A., 1994. An empirical evaluation of the argon diffusion geometry in muscovite. Earth Planet. Sci. Lett. 124, $161-167$.

Holland, T.J.B., Powell, R., 1998. An internally consistent thermodynamic data set for phases of petrological interest. J. Metamorph. Geol. 16, 309-343.

Jurdy, D.M., Stefanick, M., Scotese, C.R., 1995. Paleozoic plate dynamics. J. Geophys. Res. 100, 17965-17975.

Kaya, O., Möstler, H., 1992. A Middle Triassic age for low-grade greenschist facies metamorphic sequence in Bergama (İzmir) western Turkey: the first paleontological age assignment and structural-stratigraphic implications. Newsl. Stratigr. 26, 1-17.

Kirschner, D.L., Cosca, M.A., Masson, H., Hunziker, J.C., 1996. Staircase ${ }^{40} \mathrm{Ar} /{ }^{39} \mathrm{Ar}$ spectra of fine-grained white mica: timing 
and duration of deformation and empirical constraints on argon diffusion. Geology 24, 747-750.

Knipper, A.L., 1980. The tectonic position of ophiolites of the Lesser Caucasus. In: Panayiotou, A. (Ed.), Proceedings of the International Ophiolite Symposium, Nicosia, Cyprus, pp. $372-$ 376.

Leake, B.E., et al., 1997. Nomenclature of amphiboles. Mineral. Mag. 61, 295-321.

Maresch, W.V., Abraham, K., 1981. Petrography, mineralogy and metamorphic evolution of an eclogite from the island of Margarita, Venezuela. J. Petrol. 22, 337-362.

Maruyama, S., Cho, M., Liou, J.G., 1986. Experimental investigations of blueschist-greenschist transition equilibria: pressure dependence of $\mathrm{A} 12 \mathrm{O} 3$ contents in sodic amphiboles-a new geobarometer. In: Evans, B.W., Brown, E.H. (Eds.), Blueschists and Eclogites. Geological Society of America Memoir, vol. 164, pp. $1-16$.

Maruyama, S., Liou, J.G., Terabayashi, M., 1996. Blueschists and eclogites of the world and their exhumation. Int. Geol. Rev. 38, 485-594.

Massonne, H.-J., Schreyer, W., 1987. Phengite geobarometry based on the limiting assemblage with $\mathrm{K}$-feldspar, phlogopite and quartz. Contrib. Mineral. Petrol. 96, 212-224.

McDougall, I., Harrison, T.M., 1988. Geochronology and Thermochronology by the ${ }^{40} \mathrm{Ar} /{ }^{39} \mathrm{Ar}$ Method. Oxford Univ. Press, Oxford.

Miyashiro, A., Banno, S., 1958. Nature of glaucophanitic metamorphism. Am. J. Sci. 256, 97-110.

Monié, P., Chopin, C., 1991. ${ }^{40} \mathrm{Ar} /{ }^{39} \mathrm{Ar}$ dating in a coesite-bearing and associated units of the Dora-Maira Massif, Western Alps. Eur. J. Mineral. 3, 239-262.

Monié, P., Caby, R., Arthaud, M.H., 1997. The Neoproterozoic Brasiliano orogeny in northeast Brazil: ${ }^{40} \mathrm{Ar} /{ }^{\beta 9} \mathrm{Ar}$ and petrostructural data from Ceará. Precambrian Res. 81, 241-264.

Moore, D., 1984. Metamorphic history of a high-grade blueschist exotic block from the Franciscan Complex, California. J. Petrol. $25,126-150$.

Nebert, K., Brosch, F.J., Mörth, W., 1986. Zur Geologie und plattentektonischen Entwicklung eaines westlichen Teilabschnittes der Anatoliden-Pontiden-Sutur. Jahrb. Geol. Bundesanst. 129, $361-388$.

Oberhänsli, R., Monié, P., Candan, O., Warkus, F.C., Partzsch, J.H., Dora, O.Ö., 1998. The age of blueschist metamorphism in the Mesozoic cover series of the Menderes Massif. Schweiz. Mineral. Petrogr. Mitt. 78, 309-316.

Oh, C.W., Liou, J.G., 1990. Metamorphic evolution of two different eclogites in the Franciscan Complex California USA. Lithos 25, $41-53$.

Okay, A.I., 1982. Incipient blueschist metamorphism and metasomatism in the Tavşanlı region, northwest Turkey. Contrib. Mineral. Petrol. 79, 361-367.

Okay, A.I., 1986. High pressure/low temperature metamorphic rocks of Turkey. In: Evans, B.W., Brown, E.H. (Eds.), Blueschists and Eclogites. Geological Society of America Memoir, vol. 164 , pp. $333-348$.

Okay, A.I., 1989a. Alpine-Himalayan blueschists. Annu. Rev. Earth Planet. Sci. 17, 55-87.
Okay, A.I., 1989b. An exotic eclogite/blueschist slice in a Barrovian-style metamorphic terrain, Alanya Nappes, southern Turkey. J. Petrol. 30, 107-132.

Okay, A.I., 2000. Was the Late Triassic orogeny in Turkey caused by the collision of an oceanic plateau? In: Bozkurt, E., Winchester, J.A., Piper, J.A.D. (Eds.), Tectonics and Magmatism in Turkey and Surrounding AreaGeol. Soc. London Spec. Publ., vol. 173 , pp. $25-41$.

Okay, A.I., Monié, P., 1997. Early Mesozoic subduction in the Eastern Mediterranean: evidence from Triassic eclogite in northwest Turkey. Geology 25, 595-598.

Okay, A.I., Şahintürk, Ö., 1997. Geology of the Eastern Pontides. In: Robinson, A.G. (Ed.), Regional and Petroleum Geology of the Black Sea and Surrounding Region. Am. Ass. Petrol. Geol. (AAPG) Memoir, vol. 68, pp. 291-311.

Okay, A.I., Satır, M., 2000. Coeval plutonism and metamorphism in a latest Oligocene metamorphic core complex in northwest Turkey. Geol. Mag. 137, 495-516.

Okay, A.I., Tüysüz, O., 1999. Tethyan sutures of northern Turkey. In: Durand, B., Jolivet, L., Horváth, F., Séranne, M. (Eds.), The Mediterranean Basins: Tertiary Extension within the Alpine Orogen. Geol. Soc. London Spec. Publ., vol. 156, pp. 475-515.

Okay, A.I., Satır, M., Maluski, H., Siyako, M., Monié, P., Metzger, R., Akyüz, S., 1996. Paleo- and Neo-Tethyan events in northwestern Turkey: geologic and geochronologic constraints. In: Yin, A., Harrison, M. (Eds.), Tectonics of Asia. Cambridge Univ. Press, Cambridge, UK, pp. 420-441.

Okrusch, M., Bröcker, M., 1990. Eclogites associated with highgrade blueschists in the Cyclades archipelago, Greece: a review. Eur. J. Mineral. 2, 451-478.

Patrick, B.E., Evans, B.W., 1989. Metamorphic evolution of the Seward Peninsula blueschist terrane. J. Petrol. 30, 531-555.

Pickett, E., Robertson, A.H.F., 1996. Formation of the Late Paleozoic-Early Mesozoic Karakaya complex and related ophiolites in NW Turkey by Paleotethyan subduction-accretion. J. Geol. Soc. (Lond.) 153, 995-1009.

Philippot, P., Rumble, D., 2000. Fluid-rock interactions during high-pressure and ultrahigh-pressure metamorphism. Int. Geol. Rev. 42, 312-327.

Powell, R., Holland, T.J.B., Worley, B., 1998. Calculating phase diagrams with THERMOCALC: methods and examples. J. Metamorph. Geol. 16, 577-588.

Ridley, J., 1984. Evidence of a temperature-dependent "blueschist" to "eclogite" transformation in high-pressure metamorphism of metabasic rocks. J. Petrol. 25, 852-870.

Rojay, B., Göncüoğlu, M.C., 1997. Tectonic setting of some preLiassic low grade metamorphics in northern Anatolia. Yerbilimleri 19, 109-118.

Ruffet, G., Féraud, G., Amouric, M., 1991. Comparison of ${ }^{40} \mathrm{Ar} /{ }^{39} \mathrm{Ar}$ conventional and laser dating of biotite from the North Trégor Batholith. Geochim. Cosmochim. Acta 55, 1675-1688.

Saner, S., 1980. Palaeogeography and the depositional characteristics of the Jurassic and post-Jurassic deposits in the Mudurnu-Göynük basin (in Turkish). Türk. Jeol. Kurumu Bül. 23, $39-52$.

Scaillet, S., 1996. Excess ${ }^{40} \mathrm{Ar}$ transport scale and mechanism in high-pressure phengites: a case study from an eclogitized meta- 
basite of the Dora Maira nappe, western Alps. Geochim. Cosmochim. Acta 60, 1075-1090.

Scaillet, S., Féraud, G., Ballèvre, M., Amouric, M., 1992. Mg/Fe and $[(\mathrm{Mg}, \mathrm{Fe}) \mathrm{SiA} 2]$ compositional control on argon behaviour in high-pressure micas: a ${ }^{40} \mathrm{Ar} /{ }^{39} \mathrm{Ar}$ continuous laser-probe study from the Dora Maira nappe of the internal western Alps, Italy. Geochim. Cosmochim. Acta 56, 2851-2872.

Schliestedt, M., 1986. Eclogite-blueschist relationships as evidenced by mineral equilibria in the high-pressure metabasic rocks of Sifnos (Cycladic Islands), Greece. J. Petrol. 27, 1437-1459.

Schliested, M., Matthews, A., 1987. Transformation of blueschist to greenschist facies rocks as a consequence of fluid infiltration, Sifnos (Cyclades), Greece. Contrib. Mineral. Petrol. 97, 237-250.

Seidel, E., Kreuzer, H., Harre, W., 1982. A late Oligocene/early Miocene high pressure belt in the External Hellenides. Geol. Jahrb. E 23, 165-206.

Şengör, A.M.C., 1984. The Cimmeride orogenic system and the tectonics of Eurosia. Spec. Pap.-Geol. Soc. Am. 195 (77 pp.).

Şengör, A.M.C., Yılmaz, Y., 1981. Tethyan evolution of Turkey: a plate tectonic approach. Tectonophysics 75, 181-241.

Şentürk, K., Karaköse, C., 1981. Genesis and emplacement of the pre-Liassic ophiolite and blueschists in the Central Sakarya region (in Turkish). Türk. Jeol. Kurumu Bül. 24, 1-10.
Sherlock, S., Kelley, S.P., Inger, S., Harris, N., Okay, A.I., 1999 ${ }^{40} \mathrm{Ar}-{ }^{39} \mathrm{Ar}$ and $\mathrm{Rb}-\mathrm{Sr}$ geochronology of high-pressure metamorphism and exhumation history of the Tavsanli Zone NW Turkey. Contrib. Mineral. Petrol. 137, 46-58.

Sisson, V.B., Onstott, T.C., 1986. Dating blueschist metamorphisma combined ${ }^{40} \mathrm{Ar} /{ }^{39} \mathrm{Ar}$ and electron-microprobe approach. Geochim. Cosmochim. Acta 50, 2111-2117.

Smith, A.G., Hurley, A.M., Briden, J.C., 1981. Phanerozoic Paleocontinental World Maps Cambridge Univ. Press, Cambridge. $102 \mathrm{pp}$.

Stampfli, G.M., Borel, G.D., 2002. A plate tectonic model for the Paleozoic and Mesozoic constrained by dynamic plate boundaries and restored synthetic oceanic isochrons. Earth Planet. Sci. Lett. 196, 17-33.

Tekeli, O., 1981. Subduction complex of pre-Jurassic age northern Anatolia Turkey. Geology 9, 68-72.

Toriumi, M., 1974. Actinolite-alkali amphibole miscibility gap in an amphibole composite grain in glaucophane schist facies rock, Kanto Mountains, Japan. J. Geol. Soc. Jpn. 80, 75-80.

Yılmaz, Y., 1979. Polymetamorphism in the Söğüt-Bilecik region and its petrotectonic significance (in Turkish). Türk. Jeol. Kurumu Bül. 22, 85-100.

Yilmaz, Y., 1981. Tectonic evolution of the southern margin of the Sakarya continent (in Turkish). Istanb. Yerbilim. 1, 33-52. 